\title{
Portrait of early science education in majority dual language learner classrooms: Where do we start?
}

\author{
Brooke Rumper', Elizabeth Frechette 2, Elica Sharifnia 3, Daryl B. Greenfield 4, Roberta \\ Michnick Golinkoff ${ }^{5}$, Kathy Hirsh-Pasek ${ }^{6}$
}

\begin{abstract}
Despite the growing interest in early science education, there is much left to be explored, particularly in majority Dual Language Learning (DLL) classrooms. The current study examined 1) early science opportunities across classroom contexts in majority Spanish-English DLL Head Start classrooms, 2) the languages (i.e., English and Spanish) that teachers used to engage DLL children in science, 3) and how teachers' discussion of scientific and engineering practices and disciplinary core ideas related to children's academic outcomes. In a sample of 411 children (ages 3-5) from 34 Head Start classrooms, the current study found that teachers discussed and encouraged more practices during science lessons than circle time, dramatic play, and story time. There were no differences in teachers' discussion of core ideas across contexts. Teachers used the same amount of English and Spanish to discuss practices and core ideas. Teaching physical science was associated with children's science outcomes. Making observations and discussing life science were associated with children's math outcomes. Teaching math, making observations, and developing and using models were related to children's executive functioning. Findings from this study demonstrate that science opportunities occur across preschool classroom settings. Additionally, it provides evidence that teachers may be supporting DLL children's home language while discussing science. Finally, results indicate that teaching science supports children's academic performance in several outcomes. These findings have implications for DLL education policy as science may be a domain where teachers can support children's home language and their learning across multiple domains.
\end{abstract}

\section{Article History}

Received: 31 July 2021

Accepted: 13 October 2021

\section{Keywords}

Early science education;

Dual language learners;

Head Start; Preschool

\section{Introduction}

In recent years, within the United States, there has been a call for increased support of early science education (e.g., Office of the Press Secretary, 2016) and equitable learning environments for ethnically andlinguistically diverse populations (National Association for the Education of Young Children [NAEYC], 2019). Yet, despite this call, relatively little is known about how teachers currently engage in science within preschool classrooms (Greenfield et al., 2009; Piasta et al., 2014; Saçkes et al., 2020). Increased knowledge about how to support science learning is especially important for young Hispanic children as Hispanics are disproportionately underrepresented in Science, Technology, Engineering, Mathematics (STEM) careers (Kennedy et al., 2021; U.S. Bureau of Labor Statistics, 2020). Additionally, Hispanic children, particularly those from Spanish-speaking households, are disproportionately more likely to grow up in poverty, putting them at greater risk for early academic achievement gaps that begin early and widen over time (Duncan et al., 2007; Fitzpatrick et al., 2014; Hart \& Risley, 2003; Morgan et al., 2016). These achievement gaps affect well-studied learning domains like language (Hart \& Risley, 2003), but also critical areas like science (Morgan et al., 2016), math

\footnotetext{
${ }^{1}$ Temple University, Department of Psychology, Ambler, USA, e-mail: brooke.rumper@temple.edu, ORCID: https://orcid.org/0000-0003-4960-2566

2 University of Oklahoma-Tulsa, Early Childhood Education Institute, Tulsa, USA, e-mail: e.frechette@ou.edu, ORCID: https://orcid.org/0000-0002-7008-775X

${ }^{3}$ University of Miami, Department of Psychology, Coral Gables, USA, e-mail: ebs76@miami.edu, ORCID: https://orcid.org/0000-0003-0703-3780

4 University of Miami, Department of Psychology, Coral Gables, USA, e-mail: dgreenfield@miami.edu, ORCID: https://orcid.org/0000-0003-3692-7425

${ }^{5}$ University of Delaware, School of Education, Newark, USA, roberta@udel.edu, ORCID: https://orcid.org/0000-0003-3299-9720

${ }^{6}$ Temple University, Department of Psychology, Ambler, The Brookings Institution, USA, e-mail: kathryn.hirsh-pasek@temple.edu, ORCID: https://orcid.org/0000-0003$\underline{2947-4544}$
} 
(Duncan et al., 2007), and executive function (EF) (Fitzpatrick et al., 2014).

Research demonstrates that high-quality preschool experiences have ameliorated academic achievement gaps for Hispanic Spanish-English Dual Language Learning (DLL) children (Buysse et al., 2014; Castro et al., 2017; Yazejian et al., 2015). More specifically, teacher engagement in early science inquiry is ripe with opportunities for these high-quality interactions (Kook \& Greenfield, 2021; Whittaker et al., 2020) and has been shown to improve children's science and math skills (Piasta et al., 2015).

However, little is known about how teachers engage in early science in preschool and how teachers might specifically support DLL children in this domain (Rumper et al., 2021). In addition, few studies have investigated how preschool science affects children's outcomes in majority Hispanic, Spanish-English DLL classrooms (Banse, 2019). To address the need to support early science learning, the current study aims to paint a portrait of early science opportunities occurring in majority DLL classrooms. Furthermore, it will examine how preschool science relates to Spanish-English DLL children's academic outcomes.

\section{Current State of Early Science Education in the United States}

Recently, the Office of the Press Secretary (2016) expressed an urgent national need to advance science education for young learners. As a nation, the U.S. falls behind many developed and developing countries in science education. High school students in the U.S. ranked 38th in science achievement out of 71 listed countries (Desilver, 2017). Given the lagging science achievement of older students in the U.S. (Desilver, 2017), there is a need to understand current practice around early science education and to bolster support for young learners. As opposed to devising ways to helping older students "catch up" in the domain of science, the current study aims to examine how teachers engage in and support science in an early educational setting.

\section{A Framework for Early Science Education}

A new dynamic vision of scientific inquiry has arisen, one that diverges from the antiquated view of science education. The Framework for K-12 Science Education (National Research Council, 2012) offers a definition of science that no longer involves simply memorizing formulas or facts but allows for identifying opportunities for scientific inquiry in everyday contexts. It contains three complementary components: scientific and engineering practices, disciplinary core ideas, and crosscutting concepts (National Research Council, 2012). Scientific and engineering practices are the behaviors teachers and children engage in to support understanding (e.g., making predictions, making observations, documenting, analyzing and interpreting data, etc.). Disciplinary core ideas are the content that children learn (e.g., life science, earth and space science, physical science). Crosscutting concepts are the ubiquitous concepts children can understand from scientific inquiry to draw larger conclusions about the world (e.g., patterns, structure and function, cause and effect, etc.). Although this framework was designed for the K-12 educational system, it is flexibly adaptable for the early childhood setting and relevant for young learners (Greenfield et al., 2017; Saçkes et al., 2009; Trundle \& Saçkes, 2012). For example, on the playground, children may notice that the leaves on the trees change colors or fall off as the weather gets colder, but the tree trunk remains the same. This one example presents an opportunity for children to engage in making observations (i.e., a practice) to support their understanding of life science content (i.e., core idea) and the concept of stability and change (i.e., crosscutting concept). The current study incorporates the early childhood version of the Framework for K-12 Science Education which seamlessly connects to later science learning goals (National Research Council, 2012).

\section{Science Across Classroom Contexts}

Few studies have investigated naturally occurring early science learning opportunities in preschool classrooms (Piasta et al., 2014; Rumper et al., 2021; Tu, 2006). Although science can be promoted throughout various contexts, it is often misperceived as an isolated content domain. Due to this misconception, a great deal of research on science education in early childhood classrooms has 
focused on science as an isolated learning experience (Brenneman et al., 2009; Gerde et al., 2013). Given the boundless definition described by the Framework for K-12 Science Education, science learning can occur across multiple early childhood classroom contexts. This perspective has been adopted in several studies (Neuman, 1972; Piasta et al., 2014; Tu, 2006). Neuman (1972) viewed these opportunities as "formal", "informal", and "incidental sciencing". Piasta and colleagues (2014) investigated the science and math opportunities occurring in Head Start classrooms throughout the day and found variation across classrooms regarding the amount of time spent on science and math. However, no study to date has explored science learning opportunities that are embedded across preschool classroom contexts (i.e., circle time, story time, and dramatic play).

While these informal opportunities for science learning are present across multiple contexts, little research has explored how teachers support children's engagement in science practices and understanding of core ideas throughout a typical classroom day. Circle time is a context teachers could use to introduce science content prior to a hands-on investigation and provide opportunities for children to engage in science practices. For example, a teacher may pass around seeds at circle time for children to use their senses to make observations and make a plan for an investigation to understand what seeds need to receive in order to grow. Story time is another classroom context that can support children's science learning as teachers can encourage children to observe and describe attributes of objects within a book (e.g., the shape of various fruits), make predictions about what may happen next (e.g., the sun will dry the puddles from the rain), and note crosscutting concepts (e.g., the wind caused the girl's hat to blow off) (Kook \& Greenfield, 2021). Dramatic play is another context that lends itself well to supporting children's science learning. For example, a teacher may help children think about the crosscutting concept of scale, proportion, and quantity and help them engage in the science practice of using math as they set the table with plates and pretend food. The current study aims to expand upon this by examining teacher use of science practices and core ideas from the Early Science Framework (Greenfield et al., 2017; National Research Council, 2012) that occur during a science lesson, circle time, story time, and dramatic play.

\section{Science as Hands-on and Minds-on Learning for DLL Children}

Several recent studies have highlighted the importance of leveraging science as an engaging domain to create high-quality early learning experiences for DLL children (Brenneman et al., 2019; Lange et al., 2021) as early science learning experiences are associated with later science achievement (French, 2004; Peterson \& French, 2008). Typically, developmentally appropriate pedagogy in preschool is based on hands-on and cognitively engaging (i.e., minds-on) experiences that are responsive to children's identities and cultures (NAEYC, 2020). Science includes hands-on contextual learning (Trundle \& Smith, 2017), where teachers can use different modalities to explore relevant science content and to determine DLL children's understanding of the material (e.g., through drawings, actions, etc.) (Lee et al., 2006). Thus, even if DLL children do not yet know the words to express their understanding of phenomena (e.g., changing the angle of a ramp changes the distance a ball rolls) they are able to demonstrate their knowledge. Additionally, having hands-on experiences is particularly important for DLL children as it can decrease cognitive load and facilitate language learning (Lee et al., 2006). Early science opportunities also include a minds-on component, where children are challenged to think critically to identify and solve problems. Given that science is a rich learning domain with the potential to increase hands-on and minds-on inquiry for young DLLs, there is a need to support teachers in integrating it into their classrooms. Currently, however, there is a lack of research examining how science is implemented in preschool classrooms with Spanish-English DLL children.

\section{Language Support around Science}

In addition to a need to support early scientific inquiry, DLL children also require home language support in the classroom. Prior literature demonstrates that when teachers use Spanish in the classroom, Spanish-English DLL children have higher language, math, social-emotional skills, and better approaches to learning (Burchinal et al., 2012; Chang et al., 2007; Limlingan et al., 2020, Limlingan et al., 
2021; Raikes et al., 2019). However, many studies have found that Spanish is often used infrequently, if at all, within preschool classrooms (Franco et al., 2019; Sawyer et al., 2018). Thus, begging the question, "How are teachers using English and Spanish to discuss and engage in science?". This could be a fundamental question as DLL children enter preschool programs with varying levels of English (Baker \& Wright, 2017) and may not comprehend the specific science content vocabulary due to language barriers. One prior study (Rumper et al., 2021) found that teachers used a mix of English and Spanish during science lessons to support DLL children; however, it is unknown whether this language support around science extends to other typical contexts in early childhood classrooms. Thus, more research is needed to understand how teachers use English and Spanish to discuss and support science across classroom contexts.

\section{Science as a Learning Domain for Supporting Children's Academic Outcomes}

At a child level, studies have demonstrated associations between children's science scores and their language (Guo et al., 2016; Westerberg et al., 2021), EF (Frechette et al., 2021; Gropen et al., 2011; Nayfeld et al., 2013), approaches to learning (Bustamante et al., 2017), and math skills (Kermani \& Aldemir, 2015). Previous intervention studies indicate that when preschool teachers engage in science, there are gains in children's outcomes across multiple learning domains (Guo et al., 2016; Saçkes et al., 2020; Vitiello et al., 2019; Whittaker et al., 2020). Studies have specifically shown that children make gains in their vocabulary when teachers are involved in science interventions (Guo et al., 2016). More research, however, needs to be conducted to determine how specific teacher-level factors are related to children's academic outcomes in other domains like math, science, and EF. The few studies that have examined associations between teachers' use of science in the preschool classroom and child outcomes have exhibited mixed findings. One study conducted by Whittaker and colleagues (2020) investigated the effects of a science intervention, MyTeachingPartner- Math/Science, on children's math and science outcomes and found differences between treatment and control groups. Children whose teachers were involved in an intervention had higher math and science outcomes than children whose teachers were not. Another study discovered trend-level associations (i.e., $p<.10$ ) between teachers' use of scientific and engineering practices and children's science outcomes (Vitiello et al., 2019). In naturalistic observations, Piasta and colleagues (2015) found that children in classrooms with more opportunities for science and math learning had higher math and science outcomes. However, in other studies examining early classroom science experiences, opportunities for science learning were not associated with children's concurrent or long-term science outcomes (Saçkes et al., 2011; Saçkes et al.,2013). Given mixed findings from prior studies, it is important to further examine how science teaching relates to children's academic outcomes.

\section{Current Study}

The current study aims to fill several gaps in the literature by examining the state of science learning opportunities in preschool classrooms. Additionally, little is known about teachers' use of English and Spanish support for DLL children around science. Finally, this study aims to fill the research gap surrounding the relation between teachers' engagement in science as defined by the K-12 Framework for Science Education (National Research Council, 2012) and children's academic outcomes.

\section{Research Questions and Hypotheses}

To address the gaps in the literature, the present study

1) describes science lessons conducted in majority DLL Head Start classrooms and opportunities for early science learning throughout the day,

2) examines how preschool teachers use English and Spanish language when discussing science practices and core ideas and,

3) and examines relations between teachers' science use throughout the day and children's academic outcomes (i.e., science, math, executive functioning, and vocabulary). 
The first aim is exploratory in nature and descriptive. Given the community in which this study took place, it was hypothesized that teachers would use a mix of English and Spanish in discussing practices and core ideas (Rumper et al., 2021). It was hypothesized that children whose teachers discussed more practices and core ideas would have higher academic outcomes.

\section{Method}

\section{Participants}

Lead and assistant teachers $(N=66)$ were recruited from 34 majority Spanish-English DLL classrooms across six Head Start centers during the 2017-2018 school year. Most teachers in the study reported being Hispanic (92.40\%). See Table 1 for demographics. All teachers were female and had an average of 12.52 years of experience teaching preschool $(S D=6.25)$. The majority of teachers reported having a bachelor's degree (56.10\%). Teachers also had varying levels of experience with science professional development. The majority reported having received a moderate $(53.00 \%)$ or minimal $(22.70 \%)$ amount of professional development workshops focused on early science education.

Table 1. Teacher level demographics

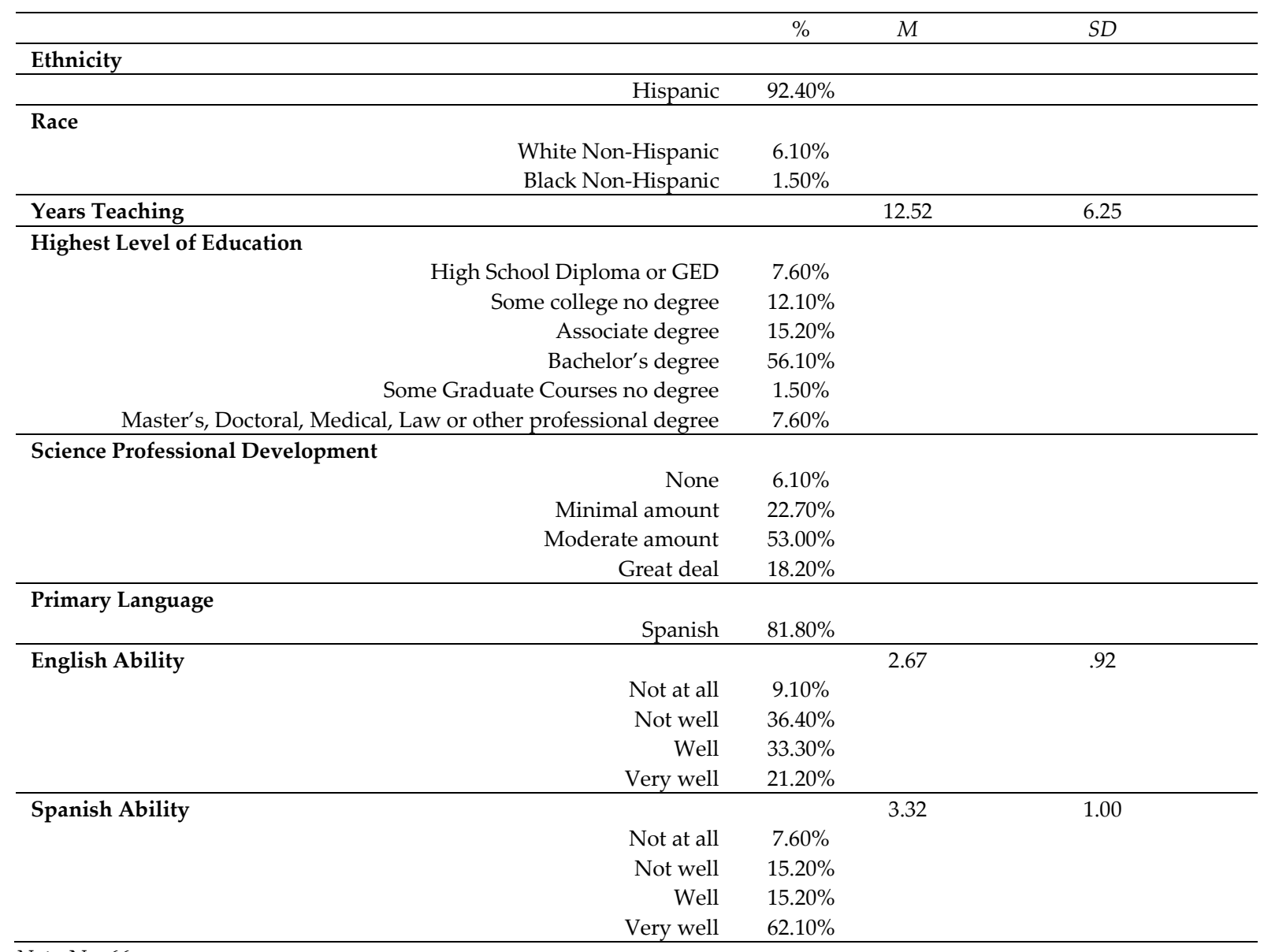

Note. $\mathrm{N}=66$.

Many teachers reported speaking some level of English, ranging from "not at all" (9.10\%) to "very well" (21.20\%). Most teachers in the study reported being able to speak some level of Spanish. Reports ranged from "not at all" $(7.60 \%)$ to "very well" $(62.10 \%)$. On average, teachers reported having higher levels of Spanish proficiency $(M=3.32, S D=1.00)$ than English proficiency $(M=2.67, S D=.92)$.

A total of 411 Spanish-English DLL Head Start children were also recruited for participation as part of a larger study. Children ranged in age from 37 to 63 months $(M=49.28, S D=6.69)$ and $48.40 \%$ were female. Classrooms contained an average of $18.83(S D=1.94)$ Spanish-English DLL children out of an average total of $19.73(S D=1.38)$ children per classroom. While Head Start Performance Standards 
state that teachers should support DLL children's English and home language development (Head Start Program Performance Standards, 2018), there is little guidance about how much each language should be used.

\section{Procedure}

Using a mixed methods approach, the current study sought to describe science occurring in majority Spanish-English DLL preschool classrooms and to examine relations between science instances and children's academic outcomes. This study was observational in nature.

The current study was approved by the Institutional Review Board of the University of Miami, protocol \#20171061. All data collection took place during the 2017-2018 school year. Head Start center directors were approached as part of a larger study, Enfoque en Ciencia (Institute of Education Sciences Grant\# R305A130612), and if they opted to participate, teachers and parents were invited to join. Participation in the study was voluntary. During the consenting process, teachers were told that the researchers were interested in learning about children's development and factors that might affect it. Participating teachers were asked to carry out four classroom routines (i.e., science lesson, circle time, story time, and dramatic play) as they normally would. They were also informed that these settings would be video recorded by trained research staff. Consenting teachers received gift cards for their participation in this study. Parents were consented for their child's participation in the study. They were told that researchers were interested in learning about children's development and school readiness and that their child would be videotaped and assessed if they chose to take part in the study.

In the fall of 2017, all children were assessed using a language screener to determine their dominant, or stronger language and EF. In the spring of 2018, children were assessed in their dominant language on science, math, and vocabulary measures. Teachers' classrooms were video-recorded on one or two mornings during the spring. Classrooms were video-recorded for 15-20 minutes in the following contexts: a science lesson, circle time, story time, and dramatic play for an average total of 58.18 minutes $(S D=12.45)$. The topic of the science lesson and the delivery format (e.g., whole group, small group, outside, etc.) were the teacher's choice.

English-Spanish bilingual undergraduate research assistants were trained to transcribe videos using Systematic Analysis of Language Transcripts (SALT) (Miller et al., 2011) conventions. Transcripts were coded for scientific and engineering practices and disciplinary core ideas using a rubric aligning with the K-12 Conceptual Framework for Science Education (National Research Council, 2012) and the Early Science Framework (Greenfield et al., 2017). See Table 2 for a description of specific science practices and core ideas coded and Appendix A for the codebook. Teachers' English and Spanish language use were coded at a word level.

\section{Measures}

\section{Scientific and Engineering Practices and Disciplinary Core Ideas}

All videos collected were transcribed according to SALT conventions (Miller et al., 2011). Thus, utterances were segmented into C-units, or independent clauses and all of their modifiers. The Early Science Framework (Greenfield et al., 2017), derived from the K-12 Framework for Science Education (National Research Council, 2012), was used to create a codebook including scientific and engineering practices and core ideas. Scientific and engineering practices and core ideas and were coded by a graduate student and undergraduate researchers in both English and Spanish at the C-unit level. For example, if a teacher used a practice or core idea in a C-unit, it was coded as that practice or core idea. Core ideas were defined as facts around science that teachers stated or requested from children. 
Table 2. Scientific and engineering practices and disciplinary core ideas coded

\begin{tabular}{|c|c|c|}
\hline \multirow{10}{*}{$\begin{array}{c}\text { Scientific and } \\
\text { engineering } \\
\text { practices: } \\
\text { the behaviors } \\
\text { that scientists } \\
\text { engage in to } \\
\text { explore and } \\
\text { develop } \\
\text { knowledge. }\end{array}$} & Science Component & Description \\
\hline & Making Observations & $\begin{array}{l}\text { How teachers encourage or help children use their senses and tools for observation to collect information about their world (e.g., using their hands to } \\
\text { feel if a rock is smooth or rough; examining a caterpillar with a magnifying glass). }\end{array}$ \\
\hline & $\begin{array}{l}\text { Asking questions and } \\
\text { defining problems }\end{array}$ & $\begin{array}{l}\text { How teachers encourage or help children to ask larger questions about what they know and what they do not (e.g., "What's inside of a ball?") or to } \\
\text { identify something that needs a solution (e.g., "The juice spilled on the floor and we need to clean it up"). }\end{array}$ \\
\hline & Making predictions & $\begin{array}{l}\text { How teachers encourage or help children use knowledge from observations and prior experiences to make an informed hypothesis (e.g., "This rock is } \\
\text { heavy. I think it will sink in the water"). }\end{array}$ \\
\hline & $\begin{array}{l}\text { Developing and using } \\
\text { models }\end{array}$ & $\begin{array}{l}\text { How teachers encourage or help children to mentally and physically represent real-world phenomena to develop and deepen their understanding (e.g., } \\
\text { drawing a house and building it in the block center). }\end{array}$ \\
\hline & $\begin{array}{l}\text { Planning and carrying out } \\
\text { investigations }\end{array}$ & $\begin{array}{l}\text { How teachers encourage or help children organize and implement a procedure to test a hypothesis (e.g., rolling marbles down ramps of varying } \\
\text { inclines to see which one goes faster). }\end{array}$ \\
\hline & $\begin{array}{l}\text { Using math and } \\
\text { computational thinking }\end{array}$ & $\begin{array}{l}\text { How teachers encourage or help children to use mathematics to quantify and describe their world (e.g., measuring the height of two plants and } \\
\text { deciding which one is taller). }\end{array}$ \\
\hline & Documenting & $\begin{array}{l}\text { How teachers encourage or help children record and organize data (e.g., drawing pictures to show which objects "sink" or "float" during an } \\
\text { experiment). }\end{array}$ \\
\hline & $\begin{array}{l}\text { Analyzing and interpreting } \\
\text { data }\end{array}$ & How teachers encourage or help children make sense of data (e.g., determining which objects "sink" or "float" after an experiment). \\
\hline & $\begin{array}{l}\text { Constructing explanations } \\
\text { and designing solutions }\end{array}$ & $\begin{array}{l}\text { How teachers encourage or help children interpret data to generate evidence-based answers to their questions and design solutions to problems (e.g., "I } \\
\text { know spiders are alive because they crawl"). }\end{array}$ \\
\hline \multirow{5}{*}{$\begin{array}{l}\text { Disciplinary } \\
\text { Core ideas: } \\
\text { the content } \\
\text { that provides } \\
\text { a context for } \\
\text { engaging in } \\
\text { practices and } \\
\text { developing an } \\
\text { understanding } \\
\text { of crosscutting } \\
\text { concepts. }\end{array}$} & Physical Science & $\begin{array}{l}\text { When teachers discuss, encourage children to discuss, or help children to learn about: } \\
\text { - Matter and its interactions } \\
\text { - } \text { Motion and stability } \\
\text { - Energy, light and sound waves, and their applications }\end{array}$ \\
\hline & Life Science & $\begin{array}{l}\text { When teachers discuss, encourage children to discuss, or help children to learn about: } \\
\text { - Molecules and organisms } \\
\text { - } \text { Ecosystems } \\
\text { - } \text { Heredity and traits } \\
\end{array}$ \\
\hline & Earth and Space Science & $\begin{array}{l}\text { When teachers discuss, encourage children to discuss, or help children to learn about: } \\
\text { - Earth's place in the universe } \\
\text { - } \quad \text { Earth's systems } \\
\text { - } \quad \text { Earth and human activity }\end{array}$ \\
\hline & Engineering and Technology & $\begin{array}{l}\text { When teachers discuss, encourage children to discuss, or help children to learn about: } \\
\text { - Engineering Design } \\
\text { - Links among engineering, technology, science, and society }\end{array}$ \\
\hline & Math & $\begin{array}{l}\text { When teachers discuss, encourage children to discuss, or help children to learn about: } \\
\text { - Shapes, sizes, sorting, patterning, and counting } \\
\text { Note: This differs from the practice "using math and computational thinking" in that the content focuses on math as a learning goal and not an action. }\end{array}$ \\
\hline
\end{tabular}


Undergraduate research assistants were trained to use the codebook derived from the Early Science Framework. Transcripts were randomly assigned to researchers and coded using Atlas.ti version 8.0. All research assistants were required to pass reliability with a Krippendorf's alpha of .67 or higher (Hayes \& Krippendorff, 2007). On average, reliability for practices was $\alpha=.82$, and for core ideas, $\alpha=$ .79.

\section{Teacher use of Spanish and English in Practices and Core Ideas}

Teachers' use of Spanish and English during practices and core ideas were also coded in Atlas.ti version 8.0. Research assistants coded English and Spanish at the individual word level or as tokens to account for code-switching. For example, on some occasions, teachers would say "baking soda" in English and the rest of the utterance in Spanish. Proper nouns, filled pause words, and singing were not coded as English or Spanish. If coders were unable to determine if a word was English or Spanish (e.g., solar, rural, etc.), they went back to the recording. Using the codes from practices and core ideas and English and Spanish language codes, percent scores were computed. For example, to determine the percent of English used during practices, the number of English words used during practices was divided by the total number of English and Spanish words used during practices and multiplied by 100 . This process was used to calculate four scores for each teacher: percent of English used during practices, percent of Spanish used during practices, percent of English used during core ideas, and percent of Spanish used during core ideas.

\section{Dominant Language}

Children were assessed using a language screener in English and Spanish to determine their dominant, or stronger language using two subtests of the prelas2000 (Duncan \& De Avila, 1998). The Art Show subtest was used to gauge children's expressive language and has a reliability of $\alpha=.90$. The Simon Says subtest was used to screen children's receptive language skills and has a Cronbach's alpha of .88. The use of these two subtests to screen Head Start DLL children has been deemed valid and reliable (Rainelli et al., 2017). Children's English Art Show and Simon Says were added to create an "English" score and their scores on the Spanish versions of these subtests were added to create a "Spanish" score. The "English" and "Spanish" scores were compared. If English was higher, children were deemed "English dominant" and received subsequent assessments in English. Comparably, if the Spanish score was higher, children were deemed "Spanish dominant" and received the remaining assessments in Spanish.

\section{Science}

To measure science achievement, children were assessed in their dominant language on Lens on Science or Enfoque en Ciencia (Greenfield, 2015). Lens and Enfoque are equated English and Spanish versions of a computer adaptive IRT-based science assessment. These measures were created to assess a range of preschool children's science knowledge as it relates to the Framework for K-12 Science Education (National Research Council, 2012). It covers the following areas: scientific and engineering practices, crosscutting concepts, and core ideas. Lens and Enfoque have a reliability of .86 when the standard error is fixed at .34 as it was for this study. The assessment has a pool of 498 items calibrated using the dichotomous Rasch model. Generally, children receive a subset of around 35 items that are tailored to their ability level. Lens and Enfoque are administered on a touchscreen computer and children wear headphones to hear prompts instructing them to respond.

\section{Math}

The Research-based Early Mathematics Assessment-Brief (REMA-Brief) (Clements et al., 2008) was used to measure children's math abilities. The REMA-Brief is a valid and reliable tool for detecting differences in children's math achievement and is appropriate for use with preschool children. The assessment is composed of 20 items and is directly administered to children by an assessor. It is designed to cover a range of early math skills, including numerals, subitizing, counting, comparing numbers, 
composing numbers, shape, composing shapes, and patterning. It has an overall reliability of .94 and demonstrates concurrent validity with the PPVT (.74). All assessors were trained rigorously to administer the REMA-Brief to preschool children and to code their answers for correctness.

\section{Executive Function (EF)}

Children's EF skills were measured using the Pencil Tap task from the Preschool Self-Regulation Assessment (PSRA) (Rueda et al., 2005; Smith-Donald et al., 2007). Pencil Tap task is a direct assessment that measures children's inhibition, working memory, and cognitive flexibility. During this assessment, children are instructed to tap their pencil once if the assessor taps their pencil twice and vice versa. Each child is administered 16 trials and a score is obtained by taking the percent of the total number of correct trials. The Pencil Tap task demonstrates measurement equivalence across race (i.e., African American children), ethnicity (i.e., Hispanic children), and sex (Denham et al., 2012). It has good concurrent and construct validity (Smith-Donald et al., 2007) and has a reliability intraclass correlation of 1.00.

\section{Vocabulary}

The Picture Vocabulary (Vocabulario de dibujos) subtest of the Woodcock Muñoz Language Survey-Revised Normative Update (WMLS-R) (Schrank et al., 2010) was used to assess children's vocabulary. This subtest of the WMLS-R measures vocabulary and verbal ability in English and Spanish. Children name a series of stimulus pictures, which are arranged from familiar to not familiar. The reliability of this subtest is 0.91 .

\section{Results}

\section{Descriptive Statistics}

Descriptive analyses and aims 1 and 2 were conducted using SPSS version 26 (George \& Mallery, 2005). Overall teachers used more utterances discussing practices $(M=218.72, S D=121.97)$ than core ideas $(M=94.85, S D=87.82), t(410)=-5.67, p<.001$. Zero-order correlations and descriptive statistics for child and teacher level variables are reported in Table 3. All child-level academic outcomes (i.e., math, science, EF, and vocabulary) were positively correlated with one another. Age was also positively associated with all of the children's academic outcomes. Sex was only significantly associated with vocabulary, where girls scored higher than boys. Dominant language was associated with children's math and science scores, where English dominant children scored higher on these assessments than Spanish dominant children. There was a weak positive correlation between teachers' documenting, and children's math scores $\left(R^{2}=.02\right)$. Making predictions was negatively associated with children's science scores $\left(R^{2}=.01\right)$. Developing and using models was positively related to children's EF scores, where earth and space science was negatively related to children's EF scores $\left(R^{2}=.02\right)$.

Many of the practices were positively associated with one another. For example, planning and carrying out investigations was positively associated with analyzing and interpreting data, asking questions and defining problems, constructing explanations, and developing and using models. Conversely, the core ideas tended to be negatively associated, perhaps because teachers focused on one content topic as opposed to discussing multiple topics. For example, earth and space science was negatively associated with all other core ideas. There were significant positive associations between words teachers used during practices in English and words used during core ideas used in English $\left(R^{2}=.12\right)$. The relation between words used in Spanish during practices and core ideas was also positive $\left(R^{2}=.44\right)$. Spanish and English words used during practices were negatively associated $\left(R^{2}=.19\right)$.

\section{Description of Science in Majority Dual Language Learning Head Start Classrooms}

\section{Science Lessons}

Physical science lessons were most frequently taught (50.00\%) followed by life science $(23.50 \%)$, earth and space science $(17.60 \%)$, and engineering and technology/math $(8.80 \%)$ (See Table 4$)$. Making observations was the most frequently used practice, while developing and using models was the least 
Brooke RUMPER et al.

Table 3. Child and teacher level descriptive statistics and correlations

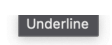

1. Math

2. Science

3. Executive Function

4. Vocabulary

5. Age

6. $\operatorname{Sex}($ boy $=1)$

7. Dominant Language (English dominant = 1)

8. Analyzing and Interpreting Data

9. Asking questions and defining problems

10. Constructing Explanations

11. Developing and Using Models

12. Documenting

13. Making Predictions

14. Making Observations

15. Planning and Carrying out Investigations

16. Using Math and Computational Thinking

17. Earth and Space Science

18. Engineering and Technology

19. Life Science

20. Physical Science

21. Math

22. Amount of English used during practices

23. Amount of Spanish used during practices

24. Amount of English used during core ideas

25. Amount of Spanish used during core ideas$$
320 \quad 11.46 \quad 3.74 \quad-
$$$$
\begin{array}{lllll}
307 & .03 & .87 & .48^{* * *} \quad-
\end{array}
$$$$
324 \quad 24.71 \quad 33.78 \quad .44^{* * *} \quad .44^{* * *} \quad-
$$$$
\begin{array}{lllllll}
316 & 439.14 & 18.97 & .42^{* * *} & .52^{* * * *} & .40^{* * * *} & -
\end{array}
$$$$
\begin{array}{lllllll}
327 & 49.28 & 6.69 & .45^{* * *} & .49^{* * * *} & 44^{* * * *} & .42^{* * *}
\end{array}
$$$$
\begin{array}{llllllll}
378 & .52 & .50 & .04 & -.08 & -.09 & -.14^{*} & .03
\end{array}
$$$$
\begin{array}{lllllllll}
411 & .32 & .47 & .21^{* * *} & .25^{* * *} & .11 & .05 & .16^{* * *} & .08
\end{array} .
$$$$
\begin{array}{lllllllllll}
411 & 20.00 & 18.01 & -.06 & -.07 & -.01 & .03 & -.08 & .01 & .01 & -
\end{array}
$$$$
\begin{array}{llllllllllll}
411 & .91 & 1.08 & .05 & .04 & .04 & .04 & -.07 & .04 & .04 & .27^{* *+*} & -
\end{array}
$$$$
\begin{array}{lllllllllllll}
411 & 5.91 & 9.78 & -.05 & -.05 & -.01 & -.02 & -.20^{* * *} & .03 & .04 & .35^{5 * *} & .28^{* * * *} & -
\end{array}
$$$$
\begin{array}{llllllllllllll}
411 & 1.56 & 3.96 & -.03 & -.02 & .13^{*} & .03 & .05 & .01 & -.02 & -.10^{*} & -.17^{* *} & -.13^{*} & -
\end{array}
$$$$
\begin{array}{lllllllllllllll}
411 & 9.21 & 14.24 & .13^{*} & .08 & .03 & .10 & .09 & .04 & .03 & .10 & .39^{* * *} & .05 & -.19 * * * & -
\end{array}
$$$$
\begin{array}{lllllllllllllll}
411 & 13.26 & 18.16 & -.04 & -.11^{*} & -.02 & -.02 & -.05 & .06 & -.10 & .27^{* * *} & .08 & .19^{* * *} & -.26^{* * *} & .39^{* * *}
\end{array}
$$$$
\begin{array}{lllllllllllllllll}
411 & 27.12 & 27.70 & .05 & -.03 & .08 & -.01 & -.05 & .06 & -.07 & -.16^{* *} & -.03 & -.03 & -.03 & .23^{* * *} & .54^{* * *} & -
\end{array}
$$

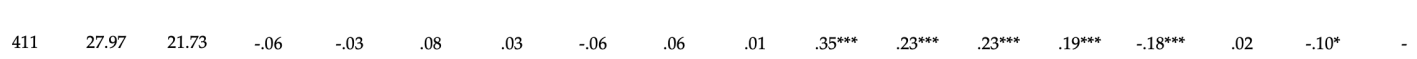

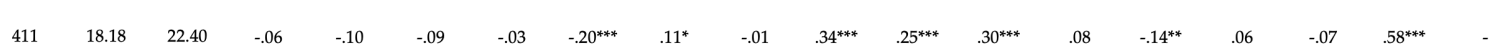$$
\begin{array}{lllllllllllllllllll}
411 & 8.82 & 19.60 & -.07 & -.10 & -.13^{*} & -.03 & -.18^{* *} & .08 & -.05 & -.05 & -.16^{* *} & .24^{* * *} & -.10^{*} & .19^{* * *} & .05 & -.05 & .03 & .10^{*}
\end{array}
$$$$
\begin{array}{lllllllllllllllllllll}
411 & 1.68 & 3.68 & -.08 & -.09 & -.04 & -.04 & -.10 & .06 & -.04 & -.11^{*} & -.16^{* * *} & .01 & .48^{* * *} & -.05 & -.08 & .07 & .19^{* * *} & .39^{* * * *} & .41^{* * *} & -
\end{array}
$$$$
\begin{array}{llllllllllllllllllllll}
411 & 26.53 & 40.00 & .07 & .02 & .06 & -.04 & .01 & .04 & -.03 & -.40^{* * *} & .11^{*} & -.16^{* *} & -.12^{* *} & .18^{* * *} & .29^{* * *} & .63^{* * * *} & -.16^{* * *} & -.11^{*} & -.20^{* * * *} & -.04 & -
\end{array}
$$$$
\begin{array}{lllllllllllllllllllllll}
411 & 7.15 & 11.26 & .04 & .09 & .07 & .05 & .01 & -.01 & .04 & .19^{* * *} & .20^{* * *} & .26^{* * *} & -.15^{* *} & -.01 & .02 & .22^{2 * *} & .03 & .01 & -.10^{*} & .06 & -.19^{* * *} & -
\end{array}
$$

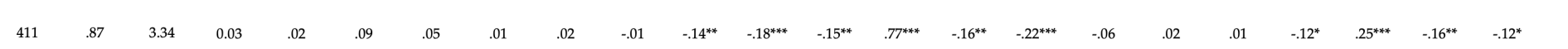$$
\begin{array}{llllllllllllllllllllllllll}
411 & 52.54 & 39.27 & .08 & .05 & -.02 & .07 & .13^{*} & -.05 & .04 & .16^{* *} & -.32^{* * *} & -.44^{* * *} & .06 & .01 & -.16^{* *} & -.19^{* * *} & -.20^{* * *} & -.22^{* * *} & -.16^{* *} & -.15^{* *} & -.33^{* * *} & .12^{*} & .27^{* * *} & -
\end{array}
$$

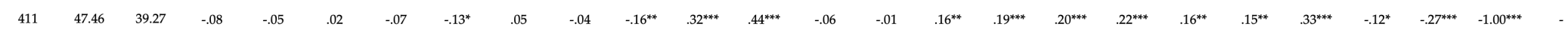

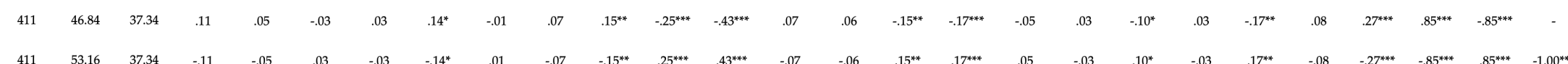

Note. Means and standard deviations are reported as raw values. Vocabulary is reported as a W Score. Practices and core ideas are totals from across all contexts. 
Table 4. Descriptions of science lessons by core idea, topic, and materials

\begin{tabular}{|c|c|c|}
\hline Core Idea & Topic & Materials \\
\hline \multirow{6}{*}{$\begin{array}{l}\text { Earth and Space } \\
\text { Science }\end{array}$} & Blowing/Wind & Straws, blue water, plates \\
\hline & Rain & Plastic cups, water, sponges, dropper, plastic syringes, bottom half of plastic bottle \\
\hline & Wind & Piece of paper, wooden blocks, feathers, cotton balls, writing utensils \\
\hline & Planet Earth & Worksheet activity, pencils, colors, scissors \\
\hline & Volcanoes & $\begin{array}{l}\text { Volcano label, 3D box with dinosaur models, plastic sheet to protect table, } 3 \text { empty water bottles, } 2 \text { bottles of vinegar, baking soda, dawn dish detergent, food coloring, } 2 \\
\text { brown cones, spoon, sheet of paper for use as cone, dinosaur toys }\end{array}$ \\
\hline & Volcanoes & Baking soda, vinegar, dish soap, funnel, empty water bottle, color food dye, bowl, sand \\
\hline \multirow{8}{*}{ Life Science } & Eggs & Eggs (one boiled, one not boiled), chart, chart paper, balance, scale, water bin \\
\hline & Plant Project & Beans, cups, water, cotton balls \\
\hline & Plant Project & cotton balls, plastic bowls, water, seeds/beans \\
\hline & Life Cycle of a Chicken & Drawings of a chicken, egg, baby chicken \\
\hline & Animals & Siamese fighting fish, pictures of animals, a shell, plastic animal toys \\
\hline & Plants (Tomatoes) & What tomatoes need to grow, paper and markers \\
\hline & Living and Non-living & plants, trays, various objects \\
\hline & Germs & Microscope, balloons, sink (water, soap, paper towels) \\
\hline \multirow{3}{*}{$\begin{array}{l}\text { Engineering and } \\
\text { Technology/Math }\end{array}$} & Counting and Measuring & White sheet, crayons, counting blocks, children's hands \\
\hline & Shapes and Lines & Shapes made from horizontal and vertical lines (squares and triangle), paper, markers, scissors \\
\hline & 3D Shapes & Markers, scissors, paper plates, glue \\
\hline \multirow{17}{*}{ Physical Science } & Sink or Float & Tub of water, wooden blocks, paper clips, rocks, rubber duck, boat, sponge \\
\hline & Sink or Float & Tub of water, chart, crayon, foam block, shell, cork, pencil, wooden block, ball, paper clip, rock \\
\hline & Sink or Float & Tub of water, a coin, scissors, paper clip, wood, feathers, rock, plastic fork, plastic football, flower \\
\hline & Sink or Float & Tub of water, various knick-knacks (rocks, fuzzy pom-poms, crayon, dinosaur toy, shark toy, cork, building blocks, puzzle pieces, stick, button, straw, cardboard box piece) \\
\hline & Sink or Float & Tub of water, container of various objects (basketball, pumpkin, pig, sailboats, ball, banana, cup, bat, butterfly, coin, wooden block, frying pan, feather, airplane) \\
\hline & Sink or Float & Tub of water, various knick-knacks (plastic cup, tomato, bat toy, wooden blocks, plastic block, plane toy, rock, butterfly toy, basketball, seashell, banana, baby bottle) \\
\hline & Sink or Float & Tub of water, foam dice, wooden block, coin, feather, scissors, chart \\
\hline & $\begin{array}{l}\text { Cooking } \\
\text { (Making caterpillars) }\end{array}$ & Celery, cream cheese, raisins, knives \\
\hline & $\begin{array}{l}\text { Cooking } \\
\text { (Making smoothies) }\end{array}$ & Water, lemon juice, sugar, strawberries, cups, spoons, straws \\
\hline & Colors of the Rainbow & paint (rainbow colors), plastic cups, paintbrushes, paper \\
\hline & Solids and Liquids & Ice, paper towel, water, spoons \\
\hline & Solutions and Suspensions & Sand, water, sugar, cups, spoons \\
\hline & Mixing Materials & Foam cup, sand, measuring cup, tub of water, paper, pencils, eraser \\
\hline & Bubbles & Dish soap, water, cups, straws \\
\hline & Magnet & Paper plates labeled 'magnetic' and 'not magnetic', magnets, rock, wooden block, magnetic letter, paper clips, clip, key chain, nail, bottle cap \\
\hline & Color Mixing & paper cup, paintbrush, white paper, colors (red and yellow) \\
\hline & $\begin{array}{l}\text { Volcano } \\
\text { (Acid/Base Reaction) }\end{array}$ & npty water bottles, vinegar, baking soda, measuring spoons, cups, balloons funnel \\
\hline
\end{tabular}


used. The most frequently observed science lesson was on "Sink or Float" (20.59\%), where teachers generally used a bin filled with water and a variety of objects to test whether items rose to the top of the water or sank to the bottom. Several teachers also conducted lessons around volcanos $(8.82 \%)$. Two of these teachers focused on aspects of volcanoes related to earth and space science (i.e., volcanoes are openings in the earth's crust that erupt). The other teacher focused more on the acid/base reaction occurring in a model volcano. Science lessons discussing animals $(11.76 \%)$ and plants $(8.82 \%)$ were other common topics covered.

Teachers were not instructed to carry out science lessons in any particular format (e.g., in whole group or small group). However, most teachers carried out lessons in small groups with an average of $9.21(S D=2.64)$ children in each science lesson. During all science lessons, teachers gave children opportunities for some type of hands-on interaction with materials.

\section{Science in Other Classroom Contexts}

Not only did teachers engage in scientific practices and core ideas during science lessons, but also other contexts within the classroom. Generally, circle time was used as a time to prepare children for the rest of the day. During circle time, teachers frequently took attendance, sang songs, and assigned classroom jobs. They also discussed the weather and phonics during this time. In a few cases, circle time was used to introduce topics that teachers planned to cover in science lessons or discuss ongoing projects. One such class was engaged in an ongoing project about tomatoes. The teacher of this classroom used circle time to review what children had learned about tomatoes.

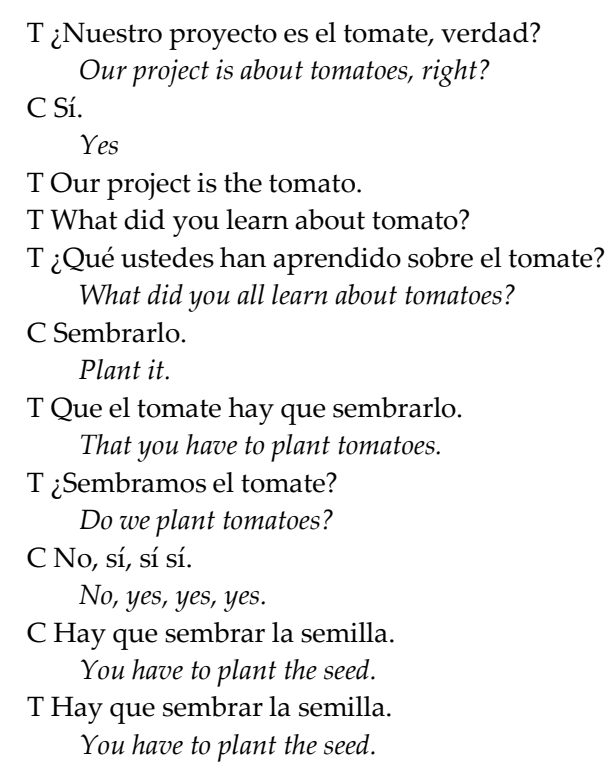

During story time, several teachers chose informational books that were specifically about science topics (e.g., insects, animals, etc.). Other teachers integrated science into works of fiction. For example, one teacher read about two caterpillars who did not get along. This teacher used the book to incorporate life science facts about caterpillars and butterflies.

T And she said that uh, Clara_Caterpillar, Clara is a caterpillar?

C No.

T What is [it] now?

C A butterfly.

T Now [it] is a butterfly.

T And what butterfly have?

T How they move?

C Wings.

T Wings. 
Finally, teachers and children also engaged in science during an informal setting: dramatic play. Most dramatic play areas contained dress-up clothes, dolls, and kitchen materials. Common topics of discussion around science included pretending to cook or playing doctor. While a child was pretended to be a doctor, one teacher discussed how medical tools were used.

$\mathrm{T}$ ¿Y tú qué estás haciendo ahí? What are you doing here?

$\mathrm{T}$ ¿Para qué se usa el estetoscopio? What do you use a stethoscope for?

C Para oír el corazón. To hear the heart.

T Para oír el corazón. To hear the heart.

T A ver, mira a ver si tú me puedes oír el mío. Let's see if you can hear mine.

\section{Science Opportunities Throughout the Day}

To examine differences in the types of practices and core ideas occurring throughout different classroom contexts, the raw number of each practice in a given context was divided by the number of minutes in each video to control for the duration (e.g., the raw number of making observations in circle time/duration of circle time). This process was also done to calculate the number of core ideas. Therefore, analyses and in-text means represent practices or core ideas/minute.

To identify whether there were differences in the number of practices/minute occurring in difference classroom contexts, a 4x9 Repeated Measures Analysis of Covariance (ANCOVA) was conducted (see Table 5 for raw means). There was a significant main effect of classroom context when controlling for teachers' highest level of education, $F(1.03,33.05)=12.74, p<.001$. In post hoc tests using Bonferroni corrections, there were significantly more practices occurring during science lessons $(M=1.72, S E=.30)$ than circle time $(M=.08, S E=.02 ; p<.001)$, dramatic play $(M=.03, S E=.02 ; p<.001)$, and story time $(M=.07, S E=.04 ; p<.001)$. There was also a significant main effect of type of practice teachers engaged in with children, $F(1.36,43.56)=12.42, p<.001$. Examining post hoc tests, teachers analyzed and interpreted data $(M=.63, S E=.13)$ more than asking questions $(M=.02, S E=.01 ; p<.01)$ and constructing explanations $(M=.17, S E=.04 ; p<.05)$. Teachers also did more planning and carrying out investigations $(M=.78, S E=.10)$ than asking questions and defining problems $(M=.02, S E=.01$; $p<.001)$, constructing explanations $(M=.17, S E=.04 ; p<.001)$, developing and using models $(M=.13$, $S E=.06 ; p<.001)$ and using math and computational thinking $(M=.38, S E=.09 ; p<.01)$. Finally, teachers used math and computational thinking more than asking questions and defining problems $(M=.02$, $S E=.01 ; p<.01)$.

Comparisons between practices indicated that teachers discussed and engaged children in some more than others. For example, teachers analyzed and interpreted data more frequently than asking questions and defining problems. Asking questions and defining problems was not coded for each individual question teachers asked children, but rather, larger questions about how to solve a problem (e.g., "We're going to see what type of objects sink and which ones float."). If teachers explicitly asked a question or defined a problem, it generally occurred one time at the introduction of a science lesson. Whereas when teachers analyzed and interpreted data, it occurred after an investigation had happened. Teachers often helped multiple individual children analyze their outcomes many times throughout the lesson (e.g., "Did your object sink or float?", "What about your object?", etc.). Analyzing and interpreting data also occurred more frequently than constructing explanations. Constructing explanations was defined as teachers supporting children in summarizing what they learned in a given experience (e.g., "The objects that are heavy are the ones that go to the bottom."). These tended to happen towards the end of the science lesson, if at all, and overall were used fairly infrequently across lessons. 
Brooke RUMPER et al.

Table 5. Descriptive statistics for practices and core ideas occurring in different classroom contexts

\begin{tabular}{|c|c|c|c|c|c|c|c|c|c|}
\hline & & \multicolumn{2}{|c|}{ Circle Time } & \multicolumn{2}{|c|}{ Dramatic Play } & \multicolumn{2}{|c|}{ Science Lesson } & \multicolumn{2}{|c|}{ Story Time } \\
\hline & & M & $S D$ & $M$ & $S D$ & $M$ & $S D$ & $M$ & $S D$ \\
\hline \multirow{9}{*}{$\begin{array}{c}\text { Scientific and } \\
\text { engineering } \\
\text { practices }\end{array}$} & Analyzing and Interpreting Data & 0.74 & 2.30 & 0.31 & 1.29 & 33.79 & 32.67 & 0.12 & 0.69 \\
\hline & $\begin{array}{r}\text { Asking Questions and Defining } \\
\text { Problems }\end{array}$ & 0.21 & 0.64 & 0.00 & 0.00 & 1.18 & 1.68 & 0.03 & 0.17 \\
\hline & Constructing Explanations & 0.24 & 0.96 & 0.18 & 1.03 & 10.79 & 17.01 & 0.03 & 0.17 \\
\hline & Developing and Using Models & 0.06 & 0.34 & 0.31 & 1.80 & 9.82 & 34.29 & 0.00 & 0.00 \\
\hline & Documenting & 3.26 & 13.96 & 0.04 & 0.26 & 12.97 & 19.44 & 0.00 & 0.00 \\
\hline & Making Observations & 4.15 & 9.59 & 2.13 & 6.42 & 41.82 & 55.32 & 4.00 & 9.54 \\
\hline & Making Predictions & 2.00 & 10.14 & 0.24 & 0.96 & 21.85 & 26.45 & 1.12 & 4.29 \\
\hline & $\begin{array}{r}\text { Planning and Carrying out } \\
\text { Investigations }\end{array}$ & 1.59 & 4.42 & 0.79 & 3.28 & 47.68 & 36.47 & 0.21 & 0.85 \\
\hline & $\begin{array}{r}\text { Using Math and Computational } \\
\text { thinking }\end{array}$ & 1.47 & 6.21 & 0.18 & 0.72 & 21.97 & 28.75 & 1.03 & 2.30 \\
\hline \multirow{5}{*}{$\begin{array}{l}\text { Disciplinary } \\
\text { core ideas }\end{array}$} & Earth and Space Science & 2.74 & 6.60 & 1.41 & 7.37 & 10.82 & 31.99 & 2.94 & 7.56 \\
\hline & Engineering and Technology & 1.32 & 4.46 & 0.49 & 1.44 & 1.65 & 4.31 & 0.44 & 2.57 \\
\hline & Life Science & 16.68 & 29.21 & 4.38 & 9.71 & 19.38 & 37.16 & 19.06 & 32.28 \\
\hline & Physical Science & 0.68 & 2.98 & 0.38 & 1.35 & 9.76 & 13.49 & 2.50 & 7.72 \\
\hline & Math & 0.00 & 0.00 & 0.00 & 0.00 & 0.74 & 3.11 & 0.00 & 0.00 \\
\hline
\end{tabular}

Note. $\mathrm{N}=34$. Means and standard deviations are reported as raw values.

Similar to analyzing and interpreting data, supporting children in planning investigations and encouraging individual children to investigate occurred frequently. For example, in a sink or float lesson, teachers asked each child one at a time to place their object into a bin of water. Thus, each child carried out their own mini-investigation while supported and encouraged by the teachers. Planning and carrying out investigations occurred more than asking questions and defining problems, constructing explanations, developing and using models, and using math and computational thinking.

A 4x5 Repeated Measures Analysis of Covariance (ANCOVA) was conducted to examine differences in the types of core ideas/minute occurring throughout different classroom settings, controlling for teachers' highest level of education. There was no significant main effect for classroom context when discussing core ideas, $F(1.36,42.78)=3.42, p>.05$. There was a significant main effect of type of core idea discussed, $F(1.12,35.76)=5.91, p<.05$. Teachers discussed more life science $(M=1.34$, $S E=.40)$ than engineering and technology $(M=.06, S E=.02 ; p<.05)$ and math $(M=.01, S E=.01 ; p<.05)$. Teachers also discussed more physical science $(M=.21, S E=.05)$ than math $(M=.01, S E=.01 ; p<.01)$.

Although there were no differences in the amount of core ideas that happened between classroom contexts, there were differences in the types of core ideas discussed. While the most common core idea taught during science lessons was physical science, teachers used more utterances throughout the day to discuss life science with children than engineering and technology and math. Most of the science lessons that were coded as engineering and technology were more math-based and had minimal engineering. For example, one teacher discussed lines for the majority of a science lesson. However, towards the end of this lesson, children began constructing shapes with these lines. Very little, if any, building occurred. Likewise, teachers also discussed physical science more than math as a core idea. Within this study, most teachers chose a science lesson that fit into the category of physical science. 


\section{Spanish and English Use when Discussing Practices and Core Ideas}

A two-way Repeated Measures ANCOVA was conducted controlling for teachers' highest level of education and primary language to determine if there were differences in teachers' use of Spanish and English when discussing practices. There were no differences between teachers' use of Spanish $(M=51.27 \%, S D=39.47)$ and English $(M=48.73 \%, S D=39.47)$ when discussing or encouraging practices, $F(1,30)=.17, p>.05$. There was an interaction between teachers' primary language and the use of Spanish and English when discussing practices, $F(1,30)=10.93, p<.01$. Teachers who reported that Spanish was their primary language used significantly more Spanish $(M=59.80, S D=36.67)$ than teachers whose primary language was English $(M=3.50, S D=5.01)$.

Another two-way Repeated Measures ANCOVA was also conducted controlling for teachers' highest level of education and primary language to determine if there were differences in teachers' use of Spanish and English when discussing core ideas. There were no differences between teachers' use of Spanish $(M=56.45 \%, S D=36.57)$ and English $(M=43.55 \%, S D=36.57)$ when discussing or encouraging core ideas, $F(1,30)=.06, p>.05$. There was an interaction between teachers' primary language and the use of Spanish and English when discussing practices, $F(1,30)=15.41, p<.001$. Teachers who reported that Spanish was their primary language used significantly more Spanish $(M=65.21, S D=32.25 \%)$ than teachers whose primary language was English $(M=7.37, S D=11.43)$.

\section{Associations Between Use of Scientific and Engineering Practices and Core Ideas and Children's Academic Outcomes}

A multilevel structural equation model (MSEM) in Mplus version 8.3 (Muthén \& Muthén, 2018) was used to determine if using practices and core ideas were related to children's science, math, EF, and vocabulary outcomes. To account for nesting, children were clustered within classrooms using Type $=$ TWOLEVEL. An intercept-only model was conducted to determine the amount of variance attributable tothe classroom level in children's academic outcomes. ICCs were calculated and very little variance was explained by classroom-level factors for science $(0.27 \%)$, math $(2.01 \%)$, EF $(3.33 \%)$, and vocabulary $(0.24 \%)$.

When examining whether scientific and engineering practices used throughout the day were associated with children's science, math, $\mathrm{EF}$, and vocabulary outcomes, model fit was excellent across fitindices for $X^{2}(2, \mathrm{~N}=411)=2.671, p>.05$, RMSEA $=.03, \mathrm{CFI}=1.00, \mathrm{SRMR}_{\text {within }}=.02$, and SRMRbetween $=.01$. When controlling for children's age, sex, and dominant language, developing and using models was positively associated with children's science, math, and EF outcomes (See Table 6). When controlling for children's age, sex, and dominant language, making observations was positively associated with children's math and EF outcomes. There were no other significant associations between the use of scientific and engineering practices and children's science, math, EF, or vocabulary outcomes.

MSEM was also used to determine if core ideas taught throughout the day were associated with children's science, math, EF, and vocabulary outcomes. Again, children were clustered within classrooms using Type $=$ TWOLEVEL. Model fit was excellent across fit indices for $X^{2}(2, N=411)=2.63$, $p>.05$, RMSEA $=.03, \mathrm{CFI}=1.00, \mathrm{SRMR}_{\text {within }}=.02$, and SRMRbetween $=.01$. Controlling for age, sex, and dominant language, physical science was positively associated with children's science outcomes, while life science was positively related to children's math outcomes. Teaching math content positively predicted children's EF outcomes. 
Table 6. Associations between children's academic outcomes and scientific and engineering practices and disciplinary core ideas throughout the day

\begin{tabular}{|c|c|c|c|c|c|c|c|c|}
\hline & \multicolumn{4}{|c|}{ Model 1} & \multicolumn{4}{|c|}{ Model 2} \\
\hline & Science & Math & $\begin{array}{l}\text { Executive } \\
\text { Function }\end{array}$ & Vocab & Science & Math & $\begin{array}{l}\text { Executive } \\
\text { Function }\end{array}$ & Vocab \\
\hline & $b(S E)$ & $b(S E)$ & $b(S E)$ & $b(S E)$ & $b(S E)$ & $b(S E)$ & $b(S E)$ & $b(S E)$ \\
\hline Age & $.48(.05)^{* * *}$ & $.45(.05)^{* * *}$ & $.45(.05)^{* * *}$ & $.44(.05)^{* * *}$ & $0.47(.05)^{* * *}$ & $.44(.05)^{* * *}$ & $.44(.05)^{* * *}$ & $.44(.05)^{* * *}$ \\
\hline Sex (1 = boy) & $-.11(.05)^{*}$ & $.01(.05)$ & $-.12(.05)^{*}$ & $-.16(.05)^{* *}$ & $-0.11(.05)^{*}$ & $.01(.05)$ & $-.12(.05)^{*}$ & $-.16(.05)^{* *}$ \\
\hline $\begin{array}{r}\text { Dominant Language } \\
\text { (1 = English Dominant) }\end{array}$ & $.17(.05)^{* *}$ & $.13(.05)^{*}$ & $.05(.05)$ & $-.02(.05)$ & $0.18(.05)^{* * *}$ & $.14(.05)^{* *}$ & $.05(.05)$ & $-.01(.05)$ \\
\hline $\begin{array}{l}\text { Analyzing and } \\
\text { Interpreting Data }\end{array}$ & $-.04(.48)$ & $-.03(38)$ & $.13(.30)$ & $.37(.49)$ & - & - & - & - \\
\hline $\begin{array}{l}\text { Asking Questions and } \\
\text { Defining Problems }\end{array}$ & $.14(.58)$ & $.17(.43)$ & $.34(.31)$ & $-.20(.52)$ & - & - & - & - \\
\hline Constructing Explanations & $.34(.64)$ & $.16(36)$ & $.34(.26)$ & $.30(.46)$ & - & - & - & - \\
\hline $\begin{array}{r}\text { Developing and Using } \\
\text { Models }\end{array}$ & $-.27(.50)$ & $-18(.30)$ & $.42(.21)^{*}$ & $.07(.34)$ & - & - & - & - \\
\hline Documenting & $.38(.65)$ & $.47(.41)$ & $-.13(.26)$ & $.69(.72) \sim$ & - & - & - & - \\
\hline Making Observations & $.39(.71)$ & $.78(.58)^{*}$ & $.62(.28)^{*}$ & $.35(.53)$ & - & - & - & - \\
\hline Making Predictions & $-1.04(1.50) \sim$ & $-.75(.64) \sim$ & $-.20(.34)$ & $-.57(.67)$ & - & - & - & - \\
\hline $\begin{array}{r}\text { Planning and Carrying } \\
\text { out Investigations }\end{array}$ & $.17(.55)$ & $-.24(.43)$ & $.50(.27) \sim$ & $.16(.51)$ & - & - & - & - \\
\hline $\begin{array}{r}\text { Using Math and } \\
\text { Computational thinking }\end{array}$ & $-.05(.48)$ & $.35(.41)$ & $-.43(.29)$ & $.47(.60)$ & - & - & - & - \\
\hline Earth and Space Science & - & - & - & - & $.34(.74)$ & $.59(.60)$ & $-.02(.33)$ & $.77(1.03)$ \\
\hline $\begin{array}{r}\text { Engineering and } \\
\text { Technology }\end{array}$ & - & - & - & - & $-.49(.97)$ & $-.57(.60)$ & $-.11(.31)$ & $-.24(.58)$ \\
\hline Life Science & - & - & - & - & $.41(.86)$ & $.88(.80)^{*}$ & $.56(.34) \sim$ & $-.03(.49)$ \\
\hline Physical Science & - & - & - & - & $.96(1.81)^{*}$ & $.59(.57)$ & $.54(.33) \sim$ & $.55(.77)$ \\
\hline Math & - & - & - & - & $.59(1.13)$ & $.63(.60) \sim$ & $.59(.32)^{*}$ & $.59(.85)$ \\
\hline
\end{tabular}

Note. $\sim p<.10,{ }^{*} p<.05,{ }^{* *} p<.01,{ }^{* * *} p<.001$

\section{Discussion}

The current study fills a gap in the literature around the need to better understand early science education in preschool classrooms. This study is the first to examine how science is embedded in majority Spanish-English DLL Head Start classrooms and found that opportunities for science learning occurred across settings. Furthermore, it investigated the language used by teachers to discuss and engage children in science; finding that teachers used both English and Spanish when discussing practices and core ideas. Finally, the current study is the first to demonstrate relations between specific science components from the Framework for K-12 Science Education (National Research Council, 2012) and children's academic outcomes.

\section{Describing Science in Majority DLL Classrooms}

Most teachers in this study chose physical science as a core idea $(50.00 \%)$ when teaching science lessons. This result differed from another study which reported that preschool teachers taught life science most frequently (56.5\% of lessons) (Vitiello et al., 2019). The topics teachers tended to cover during science lessons in this study were stereotypical science topics (e.g., sink or float lessons, volcanos, plants, animals, etc.). In a study conducted by Vitiello et al. (2019), teachers chose lessons about animals and human beings most frequently. In the current study, there were instances in which teachers chose less typical science lessons, like covering topics about states of matter. For example, in one lesson on 
melting, a teacher implemented an actual hands-on experience. Children were given two ice cubes, asked to hold one in their hand and to put the other one in a spoon. They were then asked to see which one melted faster. The differences in topics covered could demonstrate the variation in the types of science lessons teachers feel comfortable teaching (Brenneman et al., 2009).

Results from this study also indicate that science is explored across multiple preschool contexts in majority DLL classrooms. This is consistent with prior studies (Piasta et al., 2014) where teachers promoted science learning opportunities throughout the day. When examining the practices that teachers engaged children in, the majority occurred during science lessons-demonstrating that it may be important for teachers to plan experiences that actively engage children in science.

There were differences in the amount of each practice used by teachers potentially due to the nature of the particular practice. For example, some practices like planning and carrying or carrying out investigations naturally lent themselves to be used more often. Teachers helped and encouraged multiple children to engage in planning and carrying out investigations during a given context. Conversely, some practices, like constructing explantations, occurred less frequently. The practice of constructing explanations may be more challenging for teachers to support children as it requires having a learning goal for children and being able to summarize what children have learned succinctly.

There were no differences in the total amount of core ideas that occurred in different classroom contexts, indicating that teachers in this study used contexts equally to support children's science content knowledge. However, there were differences in the amount of each type of core idea teachers taught. Life science utterances occurred more frequently than engineering and technology and math. Very little engineering occurred across contexts. Perhaps, examining other contexts that were more suited towards constructing (e.g., the block area) would uncover more discussions around engineering. Interestingly, technology was also rarely discussed. Despite young children's growing access to devices, even in lower-income communities (Griffith et al., 2019), teachers rarely discussed tools or technology. This finding was similar to Vitiello and colleagues (2019), who reported that teachers rarely used science tools. Similarly, math was generally used infrequently as a core idea across classroom settings. This is consistent with a preponderance of literature in early childhood education that educators tend to focus more on literacy and language skills than science and math (Banse, 2019; Greenfield et al., 2009).

Physical science was also discussed fairly frequently across settings. Teachers were asked to conduct a science lesson and were not given specifics about what to do during the lesson. While most decided to engage in one of the four usual core ideas, some appeared more comfortable with math as a content area. This was true for only a small number of teachers. Essentially, math may have occurred less frequently than life science and physical science because teachers were specifically asked to engage in science experiences. Since science lessons are not often done explicitly in preschool settings, asking teachers to conduct science lessons might have led teachers to view the researchers as "science people" and to focus more on science while being recorded rather than topics like letter sounds.

\section{Language Support During Science Opportunities}

Consistent with a prior study, the current investigation found that teachers used Spanish to support children's learning in science (Rumper et al., 2021). This study expanded upon those findings by examining languages used to teach science in other classroom contexts, specifically examining differences in language use between practices and core ideas. Teachers used equal amounts of English and Spanish to discuss both practices and core ideas. This finding contradicts many previous studies examining the amount of Spanish used during instruction in preschool classrooms (Burchinal et al., 2012; Chang et al., 2007; Franco et al., 2019; Raikes et al., 2019; Sawyer et al., 2018), which reported that overall, teachers rarely used Spanish during instruction.

There was an interaction between Spanish use and teachers' primary language, where teachers whose primary language was Spanish used more Spanish to discuss practices and core ideas than 
English. It could be that science often involves content-specific vocabulary (Guo et al., 2016; Snow, 2010), which could be easier to discuss in one's stronger language. In this study, approximately $82 \%$ of teachers reported that Spanish was their primary language. It is unclear if teachers interpreted this question to mean "primary language" as their first language or the language they used most often. In either case, however, it speaks to the high level of Spanish proficiency of the teachers in this study.

Additionally, studies examining preschool teachers' comfort in teaching science found that teachers who received professional development in science felt more comfortable teaching science (Lange et al., 2021; Maier et al., 2013). However, other studies have found that science tends to be a domain where teachers feel less comfortable supporting children than other learning domains (Blaylock, 2019; Gerde et al., 2018). Due to this lack of comfort and self-efficacy around science, they tend to teach it less. Given the strong Spanish skills and overall lack of comfort teaching preschool science in prior research, teachers may have opted to use Spanish in formal and informal science instruction because they were more comfortable doing so.

It is also possible that teachers consciously chose to scaffold children's language development in Spanish. Again, science allows opportunities for children to learn new content-specific vocabulary (Guo et al., 2016; Snow, 2010). Most children in this study were Spanish dominant at the beginning of the preschool year $(71.30 \%)$. All teachers reported having some form of professional development around best practices for DLL children. Thus, teachers might have purposefully used Spanish to ensure that children could understand the practices (e.g., "I want you to make a prediction.") they were asked to engage in and the core ideas (e.g., "He stays inside of the chrysalis.") being taught.

\section{Associations between Science Opportunities and Children's Academic Outcomes}

As hypothesized, teaching science was beneficial across multiple child outcomes in the current study. When teachers engaged children in practices or doing science, children had higher academic outcomes. Specifically, making observations was positively associated with children's math and EF outcomes. This could be because making observations often included descriptions about size, weight, and shape (e.g., "How many are there?", "Is it heavy or light?", "What shape are eggs?"), which are important math skills. Making observations also required children to attend to certain aspects about objects or phenomena and describe characteristics that were not previously described by others (e.g., "She says it's white, can you tell me something else about this egg?"). Thus, making observations might boost children's attention and working memory skills. Developing and using models was positively related to children's EF skills. When teachers engaged children in developing and using models, they were also required to draw upon EF skills like cognitive flexibility. Children must consider the actual object and think about how to represent it with materials that they have. For example, if children are making a model airplane, they must think about the parts that make up actual airplanes (e.g., wings, wheels, windows, etc.). Children must then take their knowledge about this item and think critically about how to represent it with items they have (e.g., popsicle sticks, plastic bottles, etc.).

Similarly, children's academic outcomes were positively impacted by learning and discussing core ideas. Considering physical science was related to higher science outcomes, this may reflect that physical science (e.g., exploring sinking/floating, melting, etc.) is more easily translated to hands-on experiences that give real-time in-the-moment feedback allowing children to draw immediate conclusions. In contrast, other areas, like life science, could be more difficult to provide hands-on experiences with real-time feedback. For example, several classrooms discussed plants, which usually take weeks to grow.

Likewise, animals and germs were other topics discussed. Teachers showed pictures of animals and brought in eggs; however, life science tended to lack the hands-on component, which may be important for engaging young children in learning opportunities (Zacharia et al., 2012). This might indicate that other science core ideas like engineering and technology, a prime area for immediate hands-on feedback (e.g., challenging children to build a sturdy tower), could be ideal for early science 
Portrait of early science education in majority dual language...

learning. However, given that few teachers in this study engaged in that domain, more research is needed to understand the role of immediate feedback in hands-on learning.

Though life science was not related to children's science achievement, it was positively associated with math outcomes. Much discussion around life science included making observations and using math. For example, teachers would say, "How many eyes do we have?" or "How many legs does this zebra have? Let's count", which may explain why teachers' discussion of life science was related to children's math scores.

Additionally, teaching math as a content area was associated with children's EF skills. This finding is consistent with prior studies (Clements et al., 2016; Daubert \& Ramani, 2019; Harvey \& Miller, 2017) demonstrating a relation between children's math and EF skills. This could be because math learning requires foundational skills that are critical to children's EF (Blair et al., 2008; Geary, 2010). For instance, if a teacher asks children to add two numbers together, they must consider multiple strategies (i.e., cognitive flexibility), hold mental representations of multiple values (i.e., working memory), and inhibit impulses to recite an automatized count list (i.e., inhibition) (McKinnon \& Blair, 2019). Thus, if teachers incorporate more math into their classrooms, it may be a content area that has the potential to directly support children's EF growth.

Taken together, these findings indicate that science is a critical domain to support other learning domains. Overall engagement in science education may be effective because it aligns with the 6C's (Hirsh-Pasek et al., 2020; Weisberg et al., 2016). The 6Cs, Collaboration, Communication, Critical Thinking, Creative Innovation, Confidence, and Content, are a framework for creating a successful learning environment. In considering this framework, science exploration, both formal and informal, offers the possibility for deep engagement in each of the skills. For example, when considering children working on structures in the block area with peers, children can Collaborate and Communicate in working towards a shared goal (e.g., build a tall stable tower, get a marble to go down a complex ramp structure, etc.). This experience also engages children's Critical thinking skills and Creative innovation. Children attempting to get a marble to go down then up a ramp structure have to make sure the marble gets enough velocity from the place where it is dropped to get back up the other ramp. Critical thinking and Creative innovation are engaged when children are required to test different ramp angles (i.e., cognitive flexibility) and to recall which solutions that they have already tested (i.e., working memory and attention). Those 'Aha! moments' contained in science experiences build children's confidence in their ability to solve problems and learn new information. Finally, Content is naturally present in the core ideas. In the block area, this would be "Engineering and Technology". Given the multitude of skills that children can build through science experiences, it follows that when more science opportunities occur, children have higher academic outcomes.

\section{Lack of Associations between Science Opportunities and Academic Outcomes}

While some practices and core ideas that teachers employed were associated with children's academic outcomes, many were not. It was hypothesized that practices like analyzing and interpreting data, making observations, making predictions, and core ideas overall, should relate to children's science outcomes. These practices, in particular, would align with the format of questions present in the Lens on Science and Enfoque en Ciencia assessments. For example, items in the assessment ask children to predict where a car will be after it rolls down a ramp. However, practices did not relate to children's science outcomes. The lack of associations to science outcomes is similar to findings in prior studies examining science teaching in kindergarten classrooms (Saçkes et al., 2011; Saçkes et al., 2013). These studies found that while science teaching opportunities did not relate to children's science outcomes, other factors like children's motivation did (Saçkes et al., 2011; Saçkes et al., 2013).

Additionally, practices like making observations, and using content-specific vocabulary around core ideas would seemingly relate to children's vocabulary. However, this was not the case. Interestingly, there were no significant associations between teachers' use of practices and children's 
vocabulary and science scores. This contradicted prior studies examining science teaching, which found associations to children's vocabulary. Finally, almost all science practices were expected to relate to children's EF but did not in the current study.

It is possible that the measures of science, vocabulary, and EF were too broad and not specifically tailored to the types of science and vocabulary that children were learning in their classrooms. Classrooms in this study were not in any ongoing interventions. Additionally, several of the articles present in the synthesis by Guo et al. (2016) discuss measures targeted towards gauging specific vocabulary associated with the interventions, as opposed to using standardized assessments that capture a wide range of vocabulary terms. The same might be true of the science assessment used in the current study. The assessment used covers a variety of early science practices and core ideas (Kook \& Greenfield, 2021). Furthermore, the EF measure was also not context-specific and was more a measure of children's inhibition skills. Honing the academic assessments to better align with the practices and core ideas children are learning could uncover more direct relations to these outcomes.

\section{Implications}

Findings from this study hold implications for classroom practice and future research around early science interventions and professional development. Regarding teacher practice, most scientific and engineering practices were observed during an actual science lesson indicating that to boost active engagement around science, it may be important to support teachers in creating intentional, planned experiences. Additionally, it could suggest that teachers require training to see the science in other everyday contexts. Conversely, there were no differences in the number of core ideas occurring across classroom settings. This indicates that teachers may view all contexts as opportunities to discuss different science content.

For early science interventions and professional development, this study indicates that Head Start teachers are engaging in science across preschool contexts, demonstrating that there is a strong foundation on which to build teachers' pedagogical content knowledge in this area. Given the opportunities already occurring during story time, teachers could use a mix of informational and fiction books to more intentionally incorporate science learning opportunities into this context. During circle time, interventions could encourage teachers to infuse more science into discussions around the weather. When teaching phonics and letters, interventions could ask teachers to use words related to ongoing science projects (e.g., writing and sounding out the word "tomato" if children are learning about tomatoes). Circle time also appeared to be an important context for preparing children for the day. In this area, interventions might consider having teachers ask children what they already know about a specific science topic. Finally, in the dramatic play area, teachers could add more materials that spark discussions around science (e.g., more doctor-related materials, a variety of kitchen items with different functions, etc.). Teachers could also hold more nuanced conversations about cooking different foods or (e.g., "How is the plastic fruit different from fruit that you eat at home?" or "When daddy cooks real eggs, how do they change?").

From a programmatic standpoint, Head Start supports the use of children's home language in majority DLL classrooms (Head Start Program Performance Standards, 2018). The current study joins the corpus of literature around teachers' language use in Head Start (Burchinal et al., 2012; Chang et al., 2007; Franco et al., 2019; Raikes et al., 2019; Sawyer et al., 2018) but offers a perspective from a sample where most teachers reported speaking children's home language at least a little. The current study demonstrates that contexts do exist where teachers provide language support for DLL children and show some of the factors that could impact home language use in the classroom (e.g., teachers' language abilities). This could be useful in cultural contexts where teachers have similar demographic characteristics with children; however, not all Head Start classrooms have access to bilingual teachers. Thus, there is a need to identify malleable factors which could support DLL children's science learning in both of their languages (e.g., inviting parents the classroom to help out during science experiences, 
asking parents to send pictures of science happening at home, and to discuss them with children in the home language, etc.).

\section{Limitations and Future Directions}

While the current study has made important contributions to the literature on early science education and support of DLL children, there are several limitations. First, this study examined two important components of the K-12 Science Framework for education (Greenfield et al., 2017; National Research Council, 2012), namely practices and core ideas. However, there is a need for future studies to examine how teachers' incorporation of crosscutting concepts might affect academic outcomes. Crosscutting concepts are critical for understanding big picture ideas about how the world works and support children's learning across domains. Future studies examining science education within preschool classrooms should include crosscutting concepts in their analyses.

Additionally, the current study did not examine the quality of the practices and core ideas that teachers used. Future studies should measure teacher pedagogy or classroom quality during science opportunities. For example, researchers should seek to understand if guided play rather than direct instruction could be a better format for supporting early science learning. This could also be done by investigating the global classroom quality or using science observation tools (Vitiello et al., 2019). One study found that during science lessons teachers had higher levels of instructional support during science lessons than other areas of the classroom (Kook \& Greenfield, 2021). However, another found that teachers had lower classrom quality during science (Gerde et al., 2018). Given these differences, more research is needed to understand the relation between science classroom instructional quality and children's academic outcomes.

Additionally, this study only examined children's academic outcomes in their dominant language. Since DLL children are learning two languages, it may be important for future studies to determine how science teaching might impact DLL children's total scores or conceptual scores (Core et al., 2013; Gross et al., 2014). Finally, studies investigating science in a preschool setting should also include more classrooms across multiple time points in their analyses. The current study had several trend-level associations (i.e., $p<.10$ ), with a larger sample size these might or might not become significant.

\section{Conclusions}

Recent national calls for attention to early science education and equity in learning have spurred an emerging body of research (NAEYC, 2019; Office of the Press Secretary, 2016). To meet these demands it is imperative that researchers and practitioners identify and support opportunities for science learning across contexts. Furthermore, especially for linguistically diverse learners, languagespecific supports should be incorporated into science learning to ensure that children build foundational science skills. Moving forward, based on compounding evidence that science is a learning domain that can support other learning areas, there is a need to prepare teachers to engage in high-quality early science interactions.

\section{Declarations}

Acknowledgments: We truly appreciate the participation of the preschool centers involved in the study. We would like to acknowledge and thank the University of Miami School Readiness Lab for working tirelessly to help to collect and code the data.

Authors' contributions: All authors (B.R., E.F., E.S. D.B.G., K.H.-P., R.M.G.) took part in conceptualization, writing-original draft preparation, reviewing, and editing.

Competing interests: The authors declare that they have no competing interests.

Funding: This research was funded by the Office of Planning Research and Evaluation, grant number GR011545, and Institute of Education Sciences grant number R305A130612. 
Brooke RUMPER et al.

\section{References}

Baker, C., \& Wright, W. E. (2017). Foundations of bilingual education and bilingualism (6th ed.). McNaughton \& Gunn Ltd.

Banse, H. W. (2019). Dual language learners and four areas of early childhood learning and development: What do we know and what do we need to learn? Early Child Development and Care, 191(9) 1-14. https://doi.org/10.1080/03004430.2019.1658086

Blair, C., Knipe, H., \& Gamson, D. (2008). Is there a role for executive functions in the development of mathematics ability? Mind, Brain, and Education, 2(2), 80-89. https://doi.org/10.1111/j.1751-228X.2008.00036.x

Blaylock, D. S. (2019). Preschool Science: An Examination of Classroom and Teacher Predictors [Unpublished Dissertation]. Utah State University.

Brenneman, K., Lange, A., \& Nayfeld, I. (2019). Integrating STEM into preschool education; Designing a professional development model in diverse settings. Early Childhood Education Journal, 47(1), 15-28. https:/doi.org/10.1007/s10643018-0912-z

Brenneman, K., Stevenson-Boyd, J., Frede, E. C., \& National Institute for Early Education Research. (2009). Math and science in preschool: Policies and practice. Preschool Policy Brief. Issue 19. New Brunswick, NJ.

Burchinal, M., Field, S., López, M. L., Howes, C., \& Pianta, R. (2012). Instruction in Spanish in pre-kindergarten classrooms and child outcomes for English language learners. Early Childhood Research Quarterly, 27(2), 188-197. https://doi.org/10.1016/j.ecresq.2011.11.003

Bustamante, A. S., White, L. J., \& Greenfield, D. B. (2017). Approaches to learning and school readiness in Head Start: Applications to preschool science. Learning $\mathcal{E}$ Individual Differences, 56, 112-118. https://doi.org/10.1016/j.lindif.2016.10.012

Buysse, V., Peisner-Feinberg, E., Páez, M., Hammer, C. S., \& Knowles, M. (2014). Effects of early education programs and practices on the development and learning of dual language learners: A review of the literature. Early Childhood Research Quarterly, 29(4), 765-785. https://doi.org/10.1016/j.ecresq.2013.08.004

Castro, D. C., Gillanders, C., Franco, X., Bryant, D. M., Zepeda, M., Willoughby, M. T., \& Méndez, L. I. (2017). Early education of dual language learners: An efficacy study of the Nuestros Niños School readiness professional development program. Early Childhood Research Quarterly, 40, 188-203. https://doi.org/10.1016/j.ecresq.2017.03.002

Chang, F., Crawford, G., Early, D., Bryant, D., Howes, C., Burchinal, M., Barbarin, O., Clifford, R., \& Pianta, R. (2007). Spanishspeaking children's social and language development in pre-kindergarten classrooms. Early Education and Development, 18(2), 243-269. https://doi.org/10.1080/10409280701282959

Clements, D. H., Sarama, J., \& Germeroth, C. (2016). Learning executive function and early mathematics: Directions of causal relations. Early Childhood Research Quarterly, 36, 79-90. https://doi.org/10.1016/j.ecresq.2015.12.009

Clements, D. H., Sarama, J. H., \& Liu, X. H. (2008). Development of a measure of early mathematics achievement using the Rasch model: The Research-Based Early Maths Assessment. Educational Psychology, 28(4), 457-482. https://doi.org/10.1080/01443410701777272

Core, C., Hoff, E., Rumiche, R., \& Señor, M. (2013). Total and conceptual vocabulary in Spanish-English bilinguals from 22 to 30 months: Implications for assessment. Journal of Speech, Language, and Hearing Research, 56(5), 1637-1649. https://doi.org/10.1044/1092-4388(2013/11-0044

Daubert, E. N., \& Ramani, G. B. (2019). Math and memory in bilingual preschoolers: The relations between bilingualism, working memory, and numerical knowledge. Journal of Cognition and Development, 20(3), $314-333$. https://doi.org/10.1080/15248372.2019.1565536

Denham, S. A., Bassett, H. H., Way, E., Mincic, M., Zinsser, K., \& Graling, K. (2012). Preschoolers' emotion knowledge: Selfregulatory foundations, and predictions of early school success. Cognition $\mathcal{E}$ Emotion, 26(4), 667-679. https://doi.org/10.1080/02699931.2011.602049

Desilver, D. (2017). U.S. students' academic achievement still lags that of their peers in many other countries. Pew Research Center. https:/www.pewresearch.org/fact-tank/2017/02/15/u-s-students-internationally-math-science/

Duncan, G. J., Dowsett, C. J., Claessens, A., Magnuson, K., Huston, A. C., Klebanov, P., Pagani, L. S., Feinstein, L., Engel, M., Brooks-Gunn, J., Sexton, H., Duckworth, K., \& Japel, C. (2007). School readiness and later achievement. Developmental Psychology, 43(6), 1428-1446. https://doi.org/10.1037/0012-1649.43.6.1428

Duncan, S. E., \& De Avila, E. A. (1998). PreLAS 2000. CTB/McGraw-Hill.

Fitzpatrick, C., McKinnon, R. D., Blair, C. B., \& Willoughby, M. T. (2014). Do preschool executive function skills explain the school readiness gap between advantaged and disadvantaged children? Learning and Instruction, 30, 25-31. https://doi.org/10.1016/j.learninstruc.2013.11.003 
Portrait of early science education in majority dual language...

Franco, X., Bryant, D. M., Gillanders, C., Castro, D. C., Zepeda, M., \& Willoughby, M. T. (2019). Examining linguistic interactions of dual language learners using the Language Interaction Snapshot (LISn). Early Childhood Research Quarterly, 48, 50-61. https://doi.org/10.1016/j.ecresq.2019.02.007

Frechette, E. M., Rumper, B. M., \& Greenfield, D. B. (2021). Executive control in dual language learning preschoolers: The association between Hot and cool executive control and science achievement. Early Childhood Research Quarterly, 55, 137-148. https://doi.org/10.1016/j.ecresq.2020.11.010

French, L. (2004). Science as the center of a coherent, integrated early childhood curriculum. Early Childhood Research Quarterly, 19(1), 138-149. https://doi.org/10.1016/j.ecresq.2004.01.004

Geary, D. C. (2010). Mathematical disabilities: Reflections on cognitive, neuropsychological, and genetic components. Learning and Individual Differences, 20(2), 130-133. https://doi.org/10.1016/j.lindif.2009.10.008

George, D., \& Mallery, P. (2005). SPSS for Windows step by step: A simple guide and reference 120 update (5th ed.). Pearson Education New Zealand

Gerde, H. K., Pierce, S. J., Lee, K., \& Van Egeren, L. A. (2018). Early childhood educators' self-efficacy in science, math, and literacy instruction and science practice in the classroom. Early Education and Development, 29(1), 70-90. https://doi.org/10.1080/10409289.2017.1360127

Gerde, H. K., Schachter, R. E., \& Wasik, B. A. (2013). Using the scientific method to guide learning: An integrated approach to early childhood curriculum. Early Childhood Education Journal, 41(5), 315-323. https://doi.org/10.1007/s10643-013-0579-4

Greenfield, D. B. (2015). Assessment in Early Childhood Science Education. In K. Cabe Trundle \& M. Saçkes (Eds.), Research in Early Childhood Science Education (pp. 353-380). Springer Netherlands. https://doi.org/10.1007/978-94-017-9505-0_16

Greenfield, D. B., Alexander, A., \& Frechette, E. (2017). Unleashing the power of science in early childhood: A foundation for high-quality interactions and learning. Zero To Three, 37(5), 13-21.

Greenfield, D. B., Jirout, J., Dominguez, X., Greenberg, A., Maier, M., \& Fuccillo, J. (2009). Science in the preschool classroom: A programmatic research agenda to improve science readiness. Early Education and Development, 20(2), $238-264$. https://doi.org/10.1080/10409280802595441

Griffith, S. F., Hanson, K. G., Rolon-Arroyo, B., \& Arnold, D. H. (2019). Promoting early achievement in low-income preschoolers in the United States with educational apps. Journal of Children and Media, 13(3), 328-344. https://doi.org/10.1080/17482798.2019.1613246

Gropen, J., Clark-Chiarelli, N., Hoisington, C., \& Ehrlich, S. B. (2011). The importance of executive function in early science education: The importance of executive function. Child Development Perspectives, 5(4), 298-304. https://doi.org/10.1111/j.1750-8606.2011.00201.x

Gross, M., Buac, M., \& Kaushanskaya, M. (2014). Conceptual scoring of receptive and expressive vocabulary measures in simultaneous and sequential bilingual children. American Journal of Speech-Language Pathology, 23(4), 574-586. https://doi.org/10.1044/2014_AJSLP-13-0026

Guo, Y., Wang, S., Hall, A. H., Breit-Smith, A., \& Busch, J. (2016). The effects of science instruction on young children's vocabulary learning: A research synthesis. Early Childhood Education Journal, 44(4), 359-367. https://doi.org/10.1007/s10643-015-0721-6

Hart, B., \& Risley, T. R. (2003). The early catastrophe: The 30 million word gap by age 3. American Educator, 27(1), 4-9.

Harvey, H. A., \& Miller, G. E. (2017). Executive function skills, early mathematics, and vocabulary in Head Start preschool children. Early Education and Development, 28(3), 290-307. https://doi.org/10.1080/10409289.2016.1218728

Hayes, A. F., \& Krippendorff, K. (2007). Answering the call for a standard reliability measure for coding data. Communication Methods \& Measures, 1(1), 77-89. https://doi.org/10.1080/19312450709336664

Head Start Program Performance Standards. (2018). Office of Head Start. https://eclkc.ohs.acf.hhs.gov/policy/45-cfr-chap-xiii

Hirsh-Pasek, K., Hadani, H. S., Blinkoff, E., \& Golinkoff, R. M. (2020). A new path to education reform: Playful learning promotes 21st century skills in school and beyond. The Brookings Institution.

Kennedy, B., Fry, R., \& Funk, C. (2021). 7 Facts about the STEM workforce. Pew Research Center. https://www.pewresearch.org/fact-tank/2018/01/09/7-facts-about-the-stem-workforce/

Kermani, H., \& Aldemir, J. (2015). Preparing children for success: Integrating science, math, and technology in early childhood classroom. Early Child Development and Care, 185(9), 1504-1527. https://doi.org/10.1080/03004430.2015.1007371

Kook, J. F., \& Greenfield, D. B. (2021). Examining variation in the quality of instructional interaction across teacher-directed activities in head start classrooms. Journal of Early Childhood Research, 19(2), 128-144. https://doi.org/10.1177/1476718X20942956 
Lange, A. A., Nayfeld, I., Mano, H., \& Jung, K. (2021). Experimental effects of a preschool STEM professional learning model on educators' attitudes, beliefs, confidence, and knowledge. Journal of Early Childhood Teacher Education, 1-31. https://doi.org/10.1080/10901027.2021.1911891

Lee, O., Buxton, C., Lewis, S., \& LeRoy, K. (2006). Science inquiry and student diversity: Enhanced abilities and continuing difficulties after an instructional intervention. Journal of Research in Science Teaching, 43(7), 607-636. https://doi.org/10.1002/tea.20141

Limlingan, M. C., McWayne, C., \& Hassairi, N. (2021). Habla conmigo: Teachers' Spanish talk and Latine dual language learners' school readiness skills. Early Education and Development, 1-21. https://doi.org/10.1080/10409289.2021.1898227

Limlingan, M. C., McWayne, C. M., Sanders, E. A., \& López, M. L. (2020). Classroom language contexts as predictors of Latinx preschool dual language learners' school readiness. American Educational Research Journal, 57(1), 339-370. https://doi.org/10.3102/0002831219855694

Maier, M. F., Greenfield, D. B., \& Bulotsky-Shearer, R. J. (2013). Development and validation of a preschool teachers' attitudes and beliefs toward science teaching questionnaire. Early Childhood Research Quarterly, 28(2), 366-378. https://doi.org/10.1016/j.ecresq.2012.09.003

McKinnon, R. D., \& Blair, C. (2019). Bidirectional relations among executive function, teacher-child relationships, and early reading and math achievement: A cross-lagged panel analysis. Early Childhood Research Quarterly, 46, 152-165. https://doi.org/10.1016/j.ecresq.2018.03.011

Miller, J. F., Andriacchi, K., \& Nockerts. (2011). Assessing language production using SALT Software: A clincian's guide to language sample analysis. SALT Software LLC.

Morgan, P. L., Farkas, G., Hillemeier, M. M., \& Maczuga, S. (2016). Science achievement gaps begin very early, persist, and are largely explained by modifiable factors. Educational Researcher, 45(1), 18-35. https://doi.org/10.3102/0013189X16633182

Muthén, L. K., \& Muthén, B. O. (2018). Mplus User's Guide. (8th ed.). Los Angeles, CA: Muthén \& Muthén

National Association for the Education of Young Children. (2019). NAEYC position statement on advancing equity in early childhood education. $\quad$ https://www.naeyc.org/sites/default/files/globally-shared/downloads/PDFs/resources/positionstatements/advancingequitypositionstatement.pdf

National Association for the Education of Young Children. (2020). NAEYC position statement on developmentally appropriate practice. $\quad$ https://www.naeyc.org/sites/default/files/globally-shared/downloads/PDFs/resources/positionstatements/dap-statement0.pdf

National Research Council. (2012). A framework for K-12 science education: Practices, crosscutting concepts, and core ideas. National Academies Press.

Nayfeld, I., Fuccillo, J., \& Greenfield, D. B. (2013). Executive functions in early learning: Extending the relationship between executive functions and school readiness to science. Learning $\mathcal{E}$ Individual Differences, 26, 81-88. https://doi.org/10.1016/j.lindif.2013.04.011

Neuman, D. (1972). Sciencing for young children. In K. R. Baker (Ed.), Ideas that work with young children. Washington, DC: National Association for the Education of Young Children.

Office of the Press Secretary. (2016). Fact sheet: Advancing active STEM education for our youngest learners [Office of the Press Secretary]. https://obamawhitehouse.archives.gov/the-press-office/2016/04/21/fact-sheet-advancing-active-stemeducation-our-youngest-learners

Peterson, S. M., \& French, L. (2008). Supporting young children's explanations through inquiry science in preschool. Early Childhood Research Quarterly, 23(3), 395-408. https://doi.org/10.1016/j.ecresq.2008.01.003

Piasta, S. B., Logan, J. A. R., Pelatti, C. Y., Capps, J. L., \& Petrill, S. A. (2015). Professional development for early childhood educators: Efforts to improve math and science learning opportunities in early childhood classrooms. Journal of Educational Psychology, 107(2), 407-422. https://doi.org/10.1037/a0037621

Piasta, S. B., Pelatti, C. Y., \& Miller, H. L. (2014). Mathematics and science learning opportunities in preschool classrooms. Early Education and Development, 25(4), 445-468. https://doi.org/10.1080/10409289.2013.817753

Raikes, H. H., White, L., Green, S., Burchinal, M., Kainz, K., Horm, D., Bingham, G., Cobo-Lewis, A., St. Clair, L., Greenfield, D., \& Esteraich, J. (2019). Use of the home language in preschool classrooms and first- and second-language development among dual-language learners. Early Childhood Research Quarterly, 47, 145-158. https://doi.org/10.1016/j.ecresq.2018.06.012

Rainelli, S., Bulotsky-Shearer, R. J., Fernandez, V. A., Greenfield, D. B., \& López, M. (2017). Validity of the first two subtests of the preschool language assessment scale as a language screener for Spanish-speaking preschool children. Early Childhood Research Quarterly, 38, 10-22. https://doi.org/10.1016/j.ecresq.2016.08.001 
Portrait of early science education in majority dual language...

Rueda, M. R., Posner, M. I., \& Rothbart, M. K. (2005). The development of executive attention: Contributions to the emergence of self-regulation. Developmental Neuropsychology, 28(2), 573-594. https://doi.org/10.1207/s15326942dn2802_2

Rumper, B. M., Frechette, E., Greenfield, D., \& Hirsh-Pasek, K. (2021). Impacts on Head Start dual language learning children's early science outcomes. Education Sciences, 11(6), 283. https://doi.org/10.3390/ educsci11060283

Saçkes, M., Trundle, K. C., \& Bell, R. L. (2013). Science learning experiences in kindergarten and children's growth in science performance in elementary grades. Education and Science, 38(167), 112-125.

Saçkes, M., Trundle, K. C., \& Flevares, L. M. (2009). Using children's literature to teach standard- based science concepts in early years. Early Childhood Education Journal, 36(5), 415-422. https://doi.org/10.1007/s10643-009-0304-5

Saçkes, M., Trundle, K. C., \& Shaheen, M. (2020). The effect of balanced learning curriculum on young children's learning of science. Early Childhood Education Journal, 48 (3), 305-312. https://doi.org 10.1007/s10643-019-00985-x.

Saçkes, M., Trundle, K. C., Bell, R. L., \& O'Connell, A. A. (2011). The influence of early science experience in kindergarten on children's immediate and later science achievement: Evidence from the early childhood longitudinal study. Journal of Research in Science Teaching, 48(2), 217-235. https://doi.org/10.1002/tea.20395

Sawyer, B., Atkins-Burnett, S., Sandilos, L., Scheffner Hammer, C., Lopez, L., \& Blair, C. (2018). Variations in classroom language environments of preschool children who are low income and linguistically diverse. Early Education and Development, 29(3), 398-416. https://doi.org/10.1080/10409289.2017.1408373

Schrank, F. A., Wendling, B., \& Alvarado, C. (2010). Woodcock-Munoz Language Survey-Revised Normative Update. Riverside Publishing Company

Smith-Donald, R., Raver, C. C., Hayes, T., \& Richardson, B. (2007). Preliminary construct and concurrent validity of the Preschool Self-regulation Assessment (PSRA) for field-based research. Early Childhood Research Quarterly, 22(2), 173187. https://doi.org/10.1016/j.ecresq.2007.01.002

Snow, C. E. (2010). Academic language and the challenge of reading for learning about science. Science, 328(5977), 450-452. https://doi.org/10.1126/science.1182597

Trundle, K. C., \& Saçkes, M. (2012). Science and early education. In R. C. Pianta, W. S. Barnett, L. M. Justice, \& S. M. Sheridan (Eds.), Handbook of Early Childhood Education (240-258). New York: Guilford Press.

Trundle, K. C., \& Smith, M. M. (2017). Preschool: A hearts-on, hands-on, minds-on model for preschool science learning. Young Children, 72(1), 80-86.

$\mathrm{Tu}, \mathrm{T}$. (2006). Preschool science environment: What is available in a preschool classroom? Early Childhood Education Journal, 33(4), 245-251. https://doi.org/10.1007/s10643-005-0049-8

U.S. Bureau of Labor Statistics. (2020). Employment in STEM occupations. U.S. Bureau of Labor Statistics. Retrieved from https://www.bls.gov/emp/tables/stem-employment.htm

Vitiello, V. E., Whittaker, J. V., Mulcahy, C., Kinzie, M. B., \& Helferstay, L. (2019). Reliability and validity of the preschool science observation measure. Early Education and Development, 30(2), 196-215. https://doi.org/10.1080/10409289.2018.1544814

Weisberg, D. S., Hirsh-Pasek, K., Golinkoff, R. M., Kittredge, A. K., \& Klahr, D. (2016). Guided play: Principles and practices. Current Directions in Psychological Science, 25(3), 177-182. https://doi.org/10.1177/0963721416645512

Westerberg, L., Litkowski, E., Finders, J. K., Gerde, H. K., Duncan, R. J., Schmitt, S. A., \& Purpura, D. J. (2021). Concurrent predictors of science core knowledge in preschool. Cognitive Development, 57, 1000981. https://doi.org/10.1016/j.cogdev.2020.100981

Whittaker, J. V., Kinzie, M. B., Vitiello, V., DeCoster, J., Mulcahy, C., \& Barton, E. A. (2020). Impacts of an early childhood mathematics and science intervention on teaching practices and child outcomes. Journal of Research on Educational Effectiveness, 13(2), 177-212. https://doi.org/10.1080/19345747.2019.1710884

Yazejian, N., Bryant, D., Freel, K., \& Burchinal, M. (2015). High-quality early education: Age of entry and time in care differences in student outcomes for English-only and dual language learners. Early Childhood Research Quarterly, 32, $23-39$. https://doi.org/10.1016/j.ecresq.2015.02.002

Zacharia, Z. C., Loizou, E., \& Papaevripidou, M. (2012). Is physicality an important aspect of learning through science experimentation among kindergarten students? Early Childhood Research Quarterly, 27(3), 447-457. https://doi.org/10.1016/j.ecresq.2012.02.004 
Appendix A

Scientific and Engineering Practices ${ }^{1}$

\begin{tabular}{|c|c|c|}
\hline & $\begin{array}{l}\text { Scientific and Engineering Practices } \\
\text { Scientific practices are the behaviors that scientists engage in to explore and develop knov } \\
\text { Are children engaging in investigations? What are teachers and children doing? }\end{array}$ & \\
\hline Codes & Description & Key words\Examples \\
\hline $\begin{array}{c}\text { Making } \\
\text { Observations }\end{array}$ & $\begin{array}{l}\text { Observing and describing is coded if teachers use, or prompt children to use their senses or tools for } \\
\text { observation to collect information about their world (e.g., using their hands to feel ifa rock is smooth or } \\
\text { rough; examining a caterpillar with a magnifying glass). } \\
\text { The teacher... } \\
\text { - observes and/or describes something related to science learning. } \\
\text { - } \quad \text { encourages children to observe and describe something that is related to sciencelearning. } \\
\text { - science learning. }\end{array}$ & $\begin{array}{l}\text { Example: } \\
\text { T Un caracol. } \\
\text { A snail. } \\
\mathrm{T} \text { ¿Cómo será? } \\
\text { What's it like? } \\
\text { T Tóquenlo. } \\
\text { Touch it. } \\
\mathrm{T} \text { ¿Duro? } \\
\text { Hard? } \\
\mathrm{T} \text { ¿Igual que la semilla? } \\
\text { Same as the seed? }\end{array}$ \\
\hline $\begin{array}{l}\text { Asking questions } \\
\text { and defining } \\
\text { problems }\end{array}$ & $\begin{array}{l}\text { Asking questions and defining problems is coded if teachers or children identify somethingthat needs } \\
\text { a solution. Science begins with a question about a phenomenon such as "What happened to my plant? } \\
\text { Why are the petals falling off? Or "What's inside of a ball?"). } \\
\text { Engineering begins with a problem that needs to be solved (such as "How can I keep my marble } \\
\text { from rolling across the room and under the furniture?") The question asked or theproblem identified } \\
\text { can lead to an investigation of answers or solutions to the problem. } \\
\text { The teacher } \\
\text { - asks questions or identifies problems related to science learning and/or identifyinga problem } \\
\text { related to science learning. } \\
\text { - points out/labels when a child asks a question or is curious or wondering about } \\
\text { - enemething, or has identified a problem related to science learning, } \\
\text { encourages a child to ask a question or identify a problem related to sciencelearning. }\end{array}$ & $\begin{array}{l}\text { Example: } \\
\text { T Ok before we paint we are gonna see how } \\
\text { we can make colors with two colors. } \\
\text { T What colors is gonna make, what coloris } \\
\text { gonna be made, ok? }\end{array}$ \\
\hline $\begin{array}{c}\text { Making } \\
\text { predictions }\end{array}$ & $\begin{array}{l}\text { Making predictions should be coded when teachers and children use knowledge fromobservations } \\
\text { and prior experiences to make an informed hypothesis (e.g., "This rock isheavy. I think it will sink } \\
\text { in the water"). } \\
\text { The teacher... } \\
\text { - makes a prediction related to science learning. } \\
\text { - labels or repeats a child's prediction related to science learning. } \\
\text { - encourages a child to make a prediction related to science learning. }\end{array}$ & $\begin{array}{l}\text { Example 1: } \\
\text { T A baby chicken. } \\
\text { T Ok, that's a good prediction. } \\
\text { T Now let's see for egg number two. } \\
\text { T What do you think is inside egg } \\
\text { number two? } \\
\text { Example 2: }\end{array}$ \\
\hline
\end{tabular}


Portrait of early science education in majority dual language...

\begin{tabular}{|c|c|c|}
\hline & $\begin{array}{l}\text { Note: A prediction is different from an explanation because it is about what they think might } \\
\text { happen preceding an experiment. }\end{array}$ & $\begin{array}{l}\mathrm{T} \text { ¿Tú creas que se hunde? } \\
\text { You think it will sink? }\end{array}$ \\
\hline $\begin{array}{l}\text { Developing and } \\
\text { using models }\end{array}$ & $\begin{array}{l}\text { Developing and using models should be coded if teachers help children mentally and physically } \\
\text { represent real world phenomena to develop and deepen their understanding (e.g.,drawing a house and } \\
\text { building it in the block center). } \\
\text { The teacher... } \\
\text { - labels a child's development or use of a model related to science learning and/orconnects a } \\
\text { child's drawing or sculpture to something in the real-world } \\
\text { encourages children to develop and use a model related to science learning and/orencourage } \\
\text { the child to make a connection between a drawing or sculpture and something in the real- } \\
\text { world } \\
\text { Note: This should only be coded in the context of creating a representation of something. Simply } \\
\text { asking children to make representational art or asking children what they have created in the art } \\
\text { center does not constitute Developing and using models. It must be clearthat the art is being done to } \\
\text { deepen and extend children's STE learning. Evidence for this comes from the conversation with } \\
\text { children. }\end{array}$ & $\begin{array}{l}\text { Example: } \\
\text { (Teacher uses cotton balls and water to } \\
\text { simulate precipitation) } \\
\text { T Todos van a tener una nubecita. } \\
\quad \text { Everybody will have a small cloud. } \\
\text { T Miren, miren mi nube que esta llenitade } \\
\text { agua. } \\
\text { Look, look my cloud is filled with water. } \\
\text { T Miren lo que le está pasando. } \\
\text { Look at what is happening. } \\
\text { T ¿Qué está haciendo? } \\
\text { What is it doing? }\end{array}$ \\
\hline $\begin{array}{l}\text { Planning and } \\
\text { carrying out } \\
\text { investigations }\end{array}$ & $\begin{array}{l}\text { Should be coded if teachers support children in organizing and implementing a procedure totest a } \\
\text { hypothesis to seek an answer to a question, or test a hypothesis (e.g., rolling marbles down ramps of } \\
\text { varying inclines to see which one goes faster). } \\
\text { The teacher... } \\
\text { - models planning and investigating for children related to science learning } \\
\text { - labels a child's planning and investigating related to science learning. } \\
\text { - encourages children to plan and investigate related to science learning. }\end{array}$ & $\begin{array}{l}\text { Example: } \\
\text { T Cada uno va a tener dos bloques de } \\
\text { hielo. } \\
\quad \text { Each one of you will have two } \\
\text { blocks of ice. } \\
\text { T Y lo que quiero que hagan, cuando } \\
\text { todos tienen los bloque de hielo> } \\
\text { And what I want you to do, whenall } \\
\text { of you have your blocks of } \\
\text { ice> } \\
\text { T Primero se los voy a poner en su manoy } \\
\text { después van a poner uno en una cuchara. } \\
\text { First, you will put them on your hand } \\
\text { and then you will put one ona spoon. } \\
\text { T Y vamos a ver lo que derrite más } \\
\text { rápido. } \\
\text { And we're going to see which } \\
\text { melts fastest. }\end{array}$ \\
\hline
\end{tabular}


Brooke RUMPER et al.

\begin{tabular}{|c|c|c|}
\hline $\begin{array}{l}\text { Using math and } \\
\text { computational } \\
\text { thinking }\end{array}$ & $\begin{array}{l}\text { Using math and computational thinking should be coded if teachers support children in using } \\
\text { mathematics to quantify and describe their world (e.g., measuring the height of twoplants and } \\
\text { deciding which one is taller). } \\
\text { The teacher: } \\
\text { - uses math and computational thinking related to science learning. labels when a child uses math } \\
\text { or computational thinking related to science learning. } \\
\text { encourages children to use math and computational thinking related to sciencelearning } \\
\text { - Note: Should not be counted if it lacks context (e.g., T The next morning at nine when they } \\
\text { opened the zoo, the seals were swimming and Edward was too.) }\end{array}$ & $\begin{array}{l}\text { Example 1: } \\
\text { T Tú lo coges y él va medir dos } \\
\text { cucharadas. } \\
\quad \text { You take it and he will measure two } \\
\quad \text { tablespoons. } \\
\text { T Two tablespoons. } \\
\text { T ¿Eh, X esto es una cucharada, this isone } \\
\text { tablespoon. } \\
\quad \text { Eh, X, this is one tablespoon? } \\
\text { Example } 2 \text { : } \\
\text { T To see the graph.T } \\
\text { How many float? } \\
\text { T One, two, three, four, five.T } \\
\text { How many sink? } \\
\text { T One, two, three, four, five. }\end{array}$ \\
\hline Documenting & $\begin{array}{l}\text { Documenting should be coded if teachers support children in recording and organizing, data(e.g., } \\
\text { drawing pictures to show which objects "sink" or "float" during an experiment). } \\
\text { The teacher } \\
\text { - documenting data for children by sorting, taking photos, making charts, etc. that isrelated to } \\
\text { science learning. } \\
\text { - labels children's documenting by using the word "document" or reminding children } \\
\text { why they are drawing, labeling, making a chart, etc. related to sciencelearning. } \\
\text { - encourages children to document data (e.g., draw, sort, make a chart, etc.) }\end{array}$ & $\begin{array}{l}\text { Example: } \\
\text { T And your hand, ok. } \\
\text { T Lo que quiero es que en este papel me } \\
\text { documenten lo que ustedes hicieron. } \\
\text { What I want is for you all to documentwhat } \\
\text { you made. } \\
\mathrm{T} \text { ¿Y el hielo que estaba en la mano quele } \\
\text { pasó? } \\
\text { What happened to the ice that was inyour } \\
\text { hand? }\end{array}$ \\
\hline
\end{tabular}


Portrait of early science education in majority dual language...

\begin{tabular}{|c|c|c|}
\hline $\begin{array}{l}\text { Analyzing and } \\
\text { interpreting data }\end{array}$ & $\begin{array}{l}\text { Analyzing and interpreting data should be coded if a teacher asks children to make sense ofdata (e.g., } \\
\text { making comparisons). } \\
\text { The teacher... } \\
\text { - encourages children to analyze and/or interpret data } \\
\text { - analyzing and/or interpreting data related to science learning. } \\
\text { Note: This code should typically be used after an experiment or after the teacher and child have } \\
\text { manipulated something. If it precedes an activity, then it will probably be "Observingand describing" }\end{array}$ & $\begin{array}{l}\text { Example 1: } \\
\text { T Ok miren lo que descubrió ella. } \\
\text { Ok look what she discovered. } \\
\text { T Que el hielo que ella tenía en su manose } \\
\text { descongeló primero que el que ella tenía en } \\
\text { la cuchara. } \\
\text { That the ice that she had in her hand melted } \\
\text { before the ice she had in the spoon. } \\
\text { Example 2: } \\
\text { T What was floating? } \\
\text { T The dice, the wooden block, the straw, the } \\
\text { feather, and the foam block. } \\
\text { T Five things. } \\
\text { T And what sunk? } \\
\text { T The penny, the key, the scissors, and } \\
\text { the crayon. } \\
\text { T So more things were floating. }\end{array}$ \\
\hline $\begin{array}{l}\text { Constructing } \\
\text { explanations and } \\
\text { designing solutions }\end{array}$ & $\begin{array}{l}\text { Constructing explanations and designing solutions should be coded when teachers supportchildren in } \\
\text { interpreting data to generate evidence-based answers to their questions and design solutions to } \\
\text { problems (e.g., "I know spiders are alive because they eat"). } \\
\text { The teacher: } \\
\text { - constructs explanations and/or designs solutions related to science learning } \\
\text { - labels when children explain or design a solution related to science learning } \\
\text { Note: This code tends to happen after analyzing and interpreting data. It is a sort of a summary about } \\
\text { what was done and what was learned as a result of something. It can also bea teacher prompting a } \\
\text { child's knowledge (e.g., How do you know that?) }\end{array}$ & $\begin{array}{l}\text { Example 1: } \\
\text { T ¿Ya después que tenemos todo esto aquí } \\
\text { adentro, ¿qué podemos decir nosotros de lo } \\
\text { que se hunde o de lo queflota? } \\
\text { After we have all of them inside, what canwe } \\
\text { tell about what sinks and what floats? } \\
\text { T A ver. Let's see. } \\
\text { T ¿Por qué flota? } \\
\text { Why does it float? } \\
\text { Example 2: } \\
\text { T The sand go down already, becausethe } \\
\text { sand is not like the sugar. } \\
\text { T It's another material, right? } \\
\text { T It doesn't dissolve in the water. }\end{array}$ \\
\hline
\end{tabular}

${ }^{1}$ Adapted from the Early Science Framework (Greenfield et al., 2017) and the Framework for K-12 Science Education (National Research Council, 2012). 
Brooke RUMPER et al.

\begin{tabular}{|c|c|c|}
\hline \multicolumn{3}{|c|}{$\begin{array}{c}\text { Disciplinary Core Ideas }{ }^{1} \\
\text { (Greenfield et al., 2017; National Research Council, 2012) }\end{array}$} \\
\hline \multicolumn{3}{|c|}{$\begin{array}{c}\text { Disciplinary core ideas are the content that provide a context for engaging in practices and developing an understanding of crosscutting concepts. } \\
\text { Are children learning science facts? }\end{array}$} \\
\hline Codes & Description & Key words\Examples \\
\hline Physical Science & $\begin{array}{l}\text { Physical Science should be coded if teachers and children discuss facts about the following: } \\
\text { - Matter and its interactions ... learning about what things are made of and how they affect each other } \\
\text { (e.g., liquid can be made solid by freezing). } \\
\text { Motion and stability ... learning about how things move or stay where they are (e.g., kicking a ball } \\
\text { - makes it roll). } \\
\text { - Lnergy ...learning about energy sources that power our world (e.g., animals eat food for energy). } \\
\text { impact on sound waves and their applications ...learning about how light and sound move and its } \\
\text { iment (e.g., light waves can be blocked by certain objects, creating a shadow). }\end{array}$ & $\begin{array}{l}\text { Example 1: } \\
\text { T1 Is the baking_soda a solid or liquid? } \\
\text { Example 2: } \\
\text { T Magnets. } \\
\text { T Remember, magnetic are X. } \\
\text { T They stick or they are pull. } \\
\text { T Or they attract to the magnet, ok? } \\
\text { T That's our magnetic. } \\
\text { T And non-magnetic is when the object is what? }\end{array}$ \\
\hline Life Science & $\begin{array}{l}\text { Life Science should be coded if teachers and children discuss facts about the following: } \\
\text { - From molecules to organisms...learning about the needs and characteristics of living things (e.g., roots } \\
\text { - help trees absorb water). } \\
\text { Ecosystems ...learning about how living things interact and use their environment to survive (e.g., birds } \\
\text { use twigs from their surroundings to build nests). } \\
\text { - Heredity and traits ...learning that living things have features that are similar andlor different from each } \\
\text { other (e.g., all dogs have fur and four legs, but some are small and others are big). } \\
\text { Biological Evolution...learning about how living things evolve and change (e.g., lizards resemble } \\
\text { dinosaurs). }\end{array}$ & $\begin{array}{l}\text { Example 1: } \\
\text { T Hay tres cosas importantes que la semilla o la } \\
\text { planta necesita para crecer. } \\
\text { There are three important things that the water or } \\
\text { the plant needs to grow. } \\
\text { T Agua, como dijo él, la lluvia, que lo podemos } \\
\text { dibujar en una columna. } \\
\text { Water, like he said, the rain that we can draw in a } \\
\text { column. } \\
\text { T El sol o los rayos del sol, que la podemos dibujar } \\
\text { en la otra columna, y lo que dijo ella, muy } \\
\text { importante. } \\
\text { The sun or the rays of the sun, that we can draw in } \\
\text { another column, and what she said, very important. } \\
\text { T ¿Qué cosa es en la otra columna? } \\
\text { What is in the other column? } \\
\text { T La tierra. } \\
\text { The earth. } \\
\text { Example } 2 \text { : } \\
\text { T Si tú vas al doctor, el doctor chequea tu garganta, } \\
\text { tu sangre. } \\
\text { If you go to the doctor, the doctor will check your } \\
\text { throat, your blood. }\end{array}$ \\
\hline
\end{tabular}


Portrait of early science education in majority dual language...

\begin{tabular}{|c|c|c|}
\hline & & $\begin{array}{l}\text { T Y poniendo algo aquí con un poquitito de sangre, } \\
\text { puede ver si tienes gérmenes. } \\
\quad \text { And putting something here with a bit of blood, He } \\
\text { can see if you have germs. } \\
\text { T Tienes virus o tiene bacteria que producen } \\
\text { enfermedades. } \\
\text { Or if you have a virus or bacteria that produces } \\
\text { illnesses. }\end{array}$ \\
\hline $\begin{array}{c}\text { Earth and Space } \\
\text { Science }\end{array}$ & $\begin{array}{l}\text { Earth and Space Science should be coded if teachers and children discuss facts about the following: } \\
\text { - Earth's place in the universe ...learning about the patterns, cycles, and movement of the earth, sun, } \\
\text { moon, and stars (e.g., the sun is visible during the day and the moon is best visible during the night). } \\
\text { - Earth's systems ...learning about the natural systems on earth and how they shape it (e.g., a squirrel lives } \\
\text { in a place with lots of trees because it uses trees for shelter and food). } \\
\text { - Earth and human activity...learning about how people and the world interact (e.g., humans need water, } \\
\text { air, and resources form the land to live). }\end{array}$ & $\begin{array}{l}\text { Example 1: } \\
\text { T Aquí, en estos lugares, como por ejemplo en el } \\
\text { Polo, la temperatura es muy fría. } \\
\text { In these places, for example the Poles, the } \\
\text { temperature is very cold. } \\
\text { T Y ahí el agua se cae en forma de nieve. } \\
\text { And there, the water falls down in the form of } \\
\text { snow. } \\
\text { T Pero aquí en nuestra ciudad cae en forma de } \\
\text { líquido y eso es lo que nosotros vamos, y eso es lo } \\
\text { que nosotros vamos a hacer. } \\
\text { But here in our city water falls down in the form } \\
\text { of liquid and this is what we, and this is what we } \\
\text { are going to do. } \\
\text { Example 2: } \\
\text { T ¿Y cómo el agua sube a las nubes, de dónde el } \\
\text { agua sube de las nubes? } \\
\text { And how does the water rise to the clouds, } \\
\text { from where does the water rise to the clouds? } \\
\text { T ¿Quién le da el agua a las nubes? } \\
\text { Who gives water to the clouds? }\end{array}$ \\
\hline
\end{tabular}


Brooke RUMPER et al.

\begin{tabular}{|c|c|c|}
\hline $\begin{array}{l}\text { Engineering and } \\
\text { Technology }\end{array}$ & $\begin{array}{l}\text { Engineering and Technology should be coded if teachers and children discuss facts about the following: } \\
\text { - Engineering Design... learning about how people design tools to help them answer questions and solve } \\
\text { problems in everyday life (e.g., a child uses a wood plank to cross a small stream on a nature walk). } \\
\text { Links among engineering, technology, science, and society... learning about how people use tools to } \\
\text { help them answer questions and solve problems in everyday life (e.g., using a magnifying glass to observe } \\
\text { the parts of a leaf). }\end{array}$ & $\begin{array}{l}\text { Example 1: } \\
\text { T What is this? } \\
\text { T Ruler. } \\
\text { T This ruler is going to help us make lines. } \\
\text { Example 2: } \\
\text { T Microscope. } \\
\text { T ¿Y para qué se usa? } \\
\text { What is it used for? }\end{array}$ \\
\hline Math & $\begin{array}{l}\text { Math should be coded if teachers and children discuss facts about the following: } \\
\text { - Shapes, sizes, sorting, patterning, and counting. } \\
\text { Note: This specifically differs from the practice, "using math and computational thinking" in that the content focuses on } \\
\text { math as a learning goal and not an action. }\end{array}$ & $\begin{array}{l}\text { Example 1: } \\
\text { T You remember that yesterday we talking when } \\
\text { we learned about the three-dimensional geometric } \\
\text { solids, yeah? } \\
\text { T And you remember what is the geometric solid } \\
\text { and the three-dimensional? } \\
\text { T A ball? } \\
\text { T A cylinder? }\end{array}$ \\
\hline
\end{tabular}

${ }^{1}$ Adapted from the Early Science Framework (Greenfield et al., 2017) and the Framework for K-12 Science Education (National Research Council, 2012). 